\title{
Poder religioso, crisis y prosperidad en Pachacamac: del Horizonte Medio al Intermedio Tardío
}

Pouvoir Religieux, Crise Et Prosperité à Pachacamac : de l'Horizon Moyen à

l'Intermediaire Récent

Religious power, crisis and prosperity in Pachacamac: from Middle Horizon to

the Late Intermediate Period

Régulo G. Franco Jordán

\section{(2) OpenEdition}

Journals

Edición electrónica

URL: http://journals.openedition.org/bifea/5074

DOI: 10.4000/bifea.5074

ISSN: 2076-5827

\section{Editor}

Institut Français d'Études Andines

\section{Edición impresa}

Fecha de publicación: 1 diciembre 2004

Paginación: 465-506

ISSN: 0303-7495

\section{Referencia electrónica}

Régulo G. Franco Jordán, « Poder religioso, crisis y prosperidad en Pachacamac: del Horizonte Medio al Intermedio Tardío », Bulletin de l'Institut français d'études andines [En línea], 33 (3) | 2004, Publicado el 08 diciembre 2004, consultado el 01 diciembre 2020. URL : http://journals.openedition.org/bifea/5074 ; DOI : https://doi.org/10.4000/bifea.5074

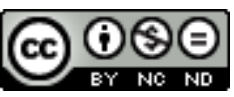

Les contenus du Bulletin de l'Institut français d'études andines sont mis à disposition selon les termes de la licence Creative Commons Attribution - Pas d'Utilisation Commerciale - Pas de Modification 4.0 International. 
Bull. Inst. fr. études andines

2004, 33 (3): 465-506

\title{
PODER RELIGIOSO, CRISIS Y PROSPERIDAD EN PACHACAMAC: DEL HORIZONTE MEDIO AL INTERMEDIO TARDÍO
}

\author{
Régulo G. FRANCO JORDÁN *
}

\section{Resumen}

Pachacamac ha sido definido como un gran centro ceremonial con mucha fama en el Antiguo Perú. Sus orígenes se remontan al Período Intermedio Temprano. En este artículo damos a conocer algunos resultados de la presencia de cambios climáticos ocurridos principalmente en el Horizonte Medio, que ocasionaron cambios sustanciales en la ideología religiosa. A partir de entonces, otras crisis climáticas ocasionaron el afincamiento de grupos de gentes altoandinas cuyos restos se encuentran debajo de las pirámides con rampa, que devino posteriormente en un replanteamiento del centro ceremonial, dando inicio a una reestructuración del mismo con la aparición de las pirámides con rampa, que vienen a ser una suerte de embajadas religiosas que representaron a los señoríos más prestigiosos de la costa central. Se discute sobre la función de las pirámides con rampa, tomando como ejemplo especialmente la Pirámide con Rampa $n^{\circ} 2$, de donde se recuperaron evidencias alfareras que, junto con las que se encontraron en el Templo Viejo, permiten establecer una secuencia temporal y estilística. Algunas interpretaciones se toman en consideración en base a los resultados de las excavaciones realizadas en las dos últimas décadas.

Palabras claves: Templo Viejo, Horizonte Medio, pirámides, Pachacamac, señorío de Ichsmay, cerámica, Costa Central, valle de Lurín.

\section{POUVOIR RELIGIEUX, CRISE ET PROSPÉRITÉ À PACHACAMAC : DE L'HORIZON MOYEN À L'INTERMÉDIAIRE RÉCENT}

\section{Résumé}

Pachacamac a été défini comme un grand centre cérémoniel très connu dans l'ancien Pérou. Ses origines remontent à l'Intermédiaire Ancien. Dans cet article nous donnons quelques

* Actual Director del Programa Arqueológico Complejo "El Brujo". Arql. de la Fundación Augusto N. Wiese. Direcc.: Av. Canaval y Moreyra 522-piso 16, San Isidro, Lima; telf. 441-2201. Email: Brujero@terra.com.pe 
résultats concernant la présence de changements climatiques survenus principalement à l'Horizon Moyen, qui ont provoqué des changements substantiels dans l'idéologie religieuse. À partir de ce moment-là, d'autres crises climatiques ont provoqué l'installation de groupes de personnes originaires des hautes Andes dont les restes ont été retrouvés sous les pyramides à rampe. Ceci provoque par la suite une remise en question du centre cérémoniel, permettant une restructuration de ce dernier avec l'apparition des pyramides à rampe, qui sont assimilées à des ambassades religieuses qui ont représenté les señoríos les plus prestigieux de la côte centrale. Le débat porte sur la fonction des pyramides à rampe, en prenant comme exemple spécifique la Pyramide à Rampe n² 2 , d'où l'on a récupéré des céramiques qui, avec celles qui ont été trouvées dans le Vieux Temple, permettent d'établir une séquence temporaire et stylistique. Quelques interprétations sont prises en considération sur la base des résultats des fouilles effectuées au cours des deux dernières décennies.

Mots clés : Vieux Temple, Horizon Moyen, pyramide, Pachacamac, señorío de Ichsmay, céramique, côte Centrale, vallée de Lurín.

\title{
RELIGIOUS POWER, CRISIS AND PROSPERITY IN PACHACAMAC: FROM MIDDLE HORIZON TO THE LATE INTERMEDIATE PERIOD
}

\begin{abstract}
Pachacamac has been defined as a great ceremonial center with much fame in Old Peru. Their origins go back Early to the Intermediate Period. In this article we present some results the presence of happened climatic changes mainly in the Average Horizon, that caused substantial changes in the religious ideology. From then, other climatic crises caused the installation of groups of people altoandinas whose rest are underneath Pyramids with Ramp, that happened later in a reframing of the ceremonial center, giving beginning to a reconstruction of the same one with the appearance of Pyramids with Ramp, that come to be a kind of religious embassies that represented the prestigious señoríos but of the central coast. The Pyramid with Ramp n 2 Incline is discussed on the function of pyramids with Ramp, taking like example specially, of where evidences recovered potters who along with those that was in the Old Temple, they allow to establish stylistic a temporary sequence and. Some interpretations are taken in consideration on the basis of the results of the excavations made in the two last decades.
\end{abstract}

Key Words: Old Temple, Middle Horizont, pyramid, Pachacamac, señorío of Ichsmay, pottery, Central Coast, valley of Lurin.

\section{INTRODUCCIÓN}

Pachacamac, con sus impresionantes estructuras ceremoniales, es uno de los sitios más importantes de la costa peruana (Fig. 1). Los resultados arqueológicos obtenidos en estos últimos años han ayudado mucho en la comprensión de la naturaleza del sitio (Eeckhout, 1995; 1999; 2003a; 2003b; Franco, 1998; Paredes, 1985; 1988; Paredes \& Franco, 1987; Shimada, 1991).

Algunos de los aspectos que discutimos son los cambios culturales ocurridos en el Horizonte Medio, gracias a las excavaciones realizadas en el Templo Viejo, a partir de lo cual se ha podido obtener datos de la aparición de un meganiño, generándose un 


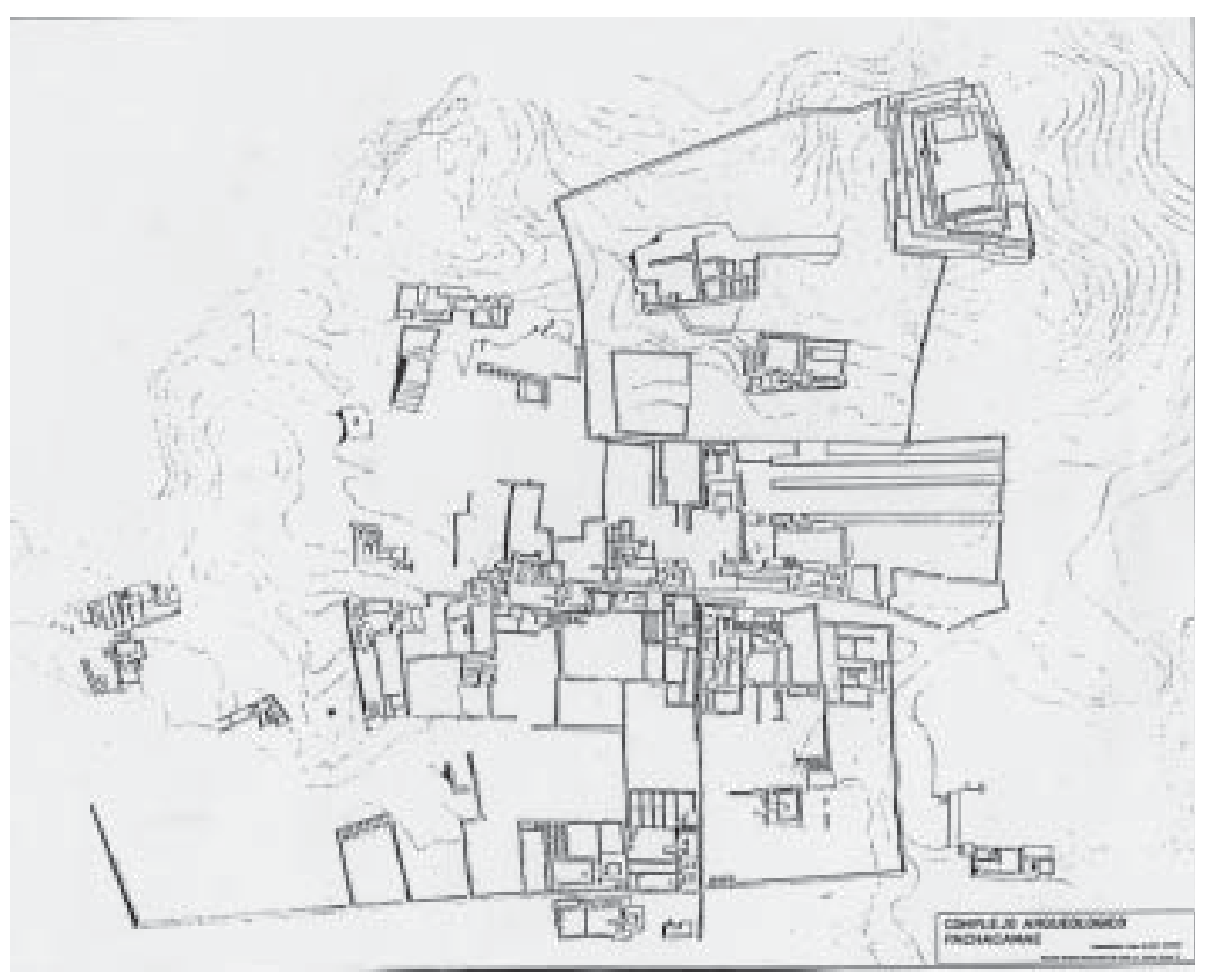

Fig. 1 - Axonometría de Pachacamac, levantado por Gladys Romero, con la asesoría del autor.

proceso de cambios en la arquitectura y la ideología de este período tan discutido por los investigadores. Ha sidoimportante encontrar la relación y aclaración cronológica del Templo Pintado en relación al Templo Viejo, que hasta hace más de una década venían siendo confundidos.

Por otro lado, planteamos algunas ideas sobre el surgimiento de las pirámides con rampa (de ahora en adelante: PCR) a raíz de una crisis climática ocurrida hacia finales de la Época 3 así como la aparición de un centro ceremonial que va a aglutinarse a una serie de edificios piramidales convertidos en una suerte de embajadas religiosas y representativas de los cacicazgos o curacazgos de mayor poder económico del señorío de Ichsmay. El mayor poder de cada representación estaba en la acumulación de mayores productos y bienes en los depósitos o almacenes que tenía cada unidad piramidal, que servían para la tributación y el comercio desarrollado en las épocas de festividades particulares y centrales.

Tomamos en cuenta una parte de la información contenida en la Pirámide con Rampa $n^{\circ} 2$, que nos ha permitido discutir el modelo, la función de sus espacios arquitectónicos y establecer comparaciones con el resto de pirámides excavadas. Es 
importante indicar que este inmueble viene a ser el modelo más completo de una pirámide conocida hasta el momento.

Otro de los aportes de este trabajo es el estudio de la cerámica a partir del Horizonte Medio, Época 3, en los diversos estilos, como la caracterización del estilo tricolor modelado encontrado en un contexto de ofrenda en el Templo Viejo, así como después el surgimiento de un estilo simple como la cerámica llana a veces pintada de color crema. Encontramos también el inciso-punzonado que es un estilo que no ha merecido todavía mucha atención, y que nos permite ahora presentar algunas muestras representativas encontradas estratigráficamente en una época anterior a la construcción de las PCR en Pachacamac. Asimismo, presentamos algunos grupos de cerámica asociados al funcionamiento de las PCR.

Considero que este trabajo en conjunto aportará algunos datos importantes para establecer una parte de la secuencia cultural de Pachacamac y la aclaración desde mi punto de vista de algunas ideas que vienen siendo discutidas en estos últimos años.

\section{EL TEMPLO VIEJO Y LA CRISIS CLIMÁTICA DURANTE EL HORIZONTE MEDIO}

Al finalizar el Intermedio Temprano, el interior del Templo Viejo tuvo representaciones pictóricas en negro sobre blanco. Su abandono se debe a copiosas lluvias que causaron gruesas capas de lodo sedimentado sobre los pisos pintados en blanco de los recintos principales. Estas capas se conservaron con improntas de pisadas de niños y adultos. No hay dudas que las lluvias que ocasionaron este hecho corresponden a un meganiño, el cual determinó la modificación del edificio y la introducción de algunos elementos constructivos ajenos a la cultura local (Franco \& Paredes, 2000: 611). Evidencias comparables provienen del grupo Tello de Cajamarquilla, donde un aluvión invadió la parte baja y posterior del edificio principal, determinando una gran modificación arquitectónica (Franco, observación personal, 1999). Este meganiño fue el primer desorden climático fuerte que se produjo a partir de la segunda mitad del primer milenio, el cual ha sido registrado como un fenómeno de consecuencias catastróficas en los Andes Centrales alrededor de los 600 D.C. (Moseley \& Feldman, 1982; Nials et al., 1979; Shimada et al., 1991; Thompson et al., 1985). La fecha de este incidente es muy temprana, lo cual hace que deberíamos tenerla en cuenta con mucho cuidado para discutir si este ha sido verdaderamente la causa del colapso de las sociedades más organizadas. De lo que sí podríamos estar seguros es que hubo un gran desorden en la estructura de las sociedades de entonces, a tal punto que la debilitada economía de las poblaciones se vio impulsada por una reorganización en los estamentos más sólidos del poder, el incremento de la producción y la interacción entre ellas (Shady, 1982). Se hace necesaria todavía una interpolación de los datos de campo para definir si este es el fenómeno climático que afecta la desocupación de los centros de poder más importantes. En el caso del Templo Viejo, su función continuó después de una gran remodelación. A partir del Horizonte Medio la relación de Pachacamac con la costa norte y sur estuvo muy fuerte, debido al prestigio y fama del oráculo de Pachacamac, que acrecentó su importancia en ambos territorios. Especialmente la diseminación de la religión desde la costa central hacia la costa norte y viceversa, produjo un sincretismo 
cerámico (Shimada, 1991: XLVIII-IL). De hecho Pachacamac cumplió el rol de mediador entre las regiones del norte y sur del mundo andino (Shady, 1982: 71).

Algunas versiones mítico-cosmológicas y de genealogía demiúrgica establecen el gran cambio cultural y de advocación a Pachacamac a partir de una nueva era de grandes movimientos migratorios y dificultades para el sostenimiento de las poblaciones costeñas durante el Horizonte Medio. De ahí que es necesario tener en cuenta una cita de Zárate tomada por Uhle (1903: 50) y más tarde retomada por Rostworowski (1977: 142-143), cuando afirma que del norte vino "Con", hijo del Sol y la Luna, a crear a los primeros hombres, y tenía poderes para transformar el poblado en desierto y ordenar que la lluvia no se produjera. A partir de entonces no hubo lluvia en la costa. Según el relato, del sur vino "Pachacamac" hijo del Sol y la Luna, desterrándolo y convirtiendo a sus criaturas en aves, monos, gatos, osos, pumas, loros y otras criaturas. Rostworowski (1977: 142), señala que el mito de Con es una manera de explicar la ausencia de agua, identificándose a esta deidad con el agua. Por otro lado Uhle (1903: 50) considera que Pachacamac personificaba los poderes creativos de la tierra, la fertilidad de los valles y que además sería un dios de significado cultural. De estas versiones se desprende algunas hipótesis de trabajo: en principio, hemos planteado (Franco \& Paredes, 2000: 611-612) que la época a la que se refiere el documento corresponde al Horizonte Medio, una época de cambios climáticos precedida por una fuerte sequía, y por otro lado, se produce un encuentro entre dos deidades tanto norteña como sureña que señala la convergencia cultural de dos tradiciones. Desde el punto de vista iconográfico, se indicaría que la divinidad del Sur corresponde a la representación del personaje llamado por Menzel front-faced deity o male deity (1964: 19; 1977: 33-55; Cf. Uhle, 1903: 26, fig.16) o "Deidad con báculo" (Cook, 1994: 176-177) de origen Tiwanaku-Wari. La versión norteña podría ser la que aparece en un textil encontrado por Ühle en Pachacamac (Uhle, 1903: 22-23, Fig. 1a; Shimada, 1991: LI) que representa a un ser sobrenatural de frente portando en sus manos una cabeza trofeo y un tumi, exornada con serpientes que rematan en cabezas de felino. La combinación de ambas representaciones originó una nueva imagen de la deidad en la versión costeña representada como un ser mítico de perfil o de frente con la cabeza de costado con rasgos felínicos portando báculos serpentiformes. Esta nueva imagen de Pachacamac de carácter agrario pertenece al grupo de dioses fertilizadores, vinculado a la iconósfera Tiwanaku-Wari (Paredes, 1991: 374-375), el cual se empezó a difundir a lo largo de la costa peruana y sierra central, y su culto se centralizó en el Templo Viejo de Pachacamac (Fig. 2). A partir del Horizonte Medio, la identidad de Pachacamac nunca cambió: lo que para Ühle es Wiracocha, pudo haber sido el mismo Coniraya, Irma-Pachacamac o Pachacamac (Paredes, 1991: 374-375).

Hay suficientes indicadores para afirmar que hubo una última remodelación del Templo Viejo. Esta última ocupación está relacionada con la introducción de un nuevo tipo de adobe de forma rectangular y de mayor espesor similar a los adobes que se encontraron en niveles profundos de la Pirámide con Rampa n 2 (Franco, 1998: 30-38). Aparecen algunas refacciones o arreglos en los muros y algunas construcciones nuevas realizadas en los sectores más importantes del templo. Del mismo modo, se emplea un pigmento verde-celeste para la decoración de los muros, reportado anteriormente para el Templo Pintado de Pachacamac (Muelle \& Wells, 1939: 276-277; Paredes \& Franco, 


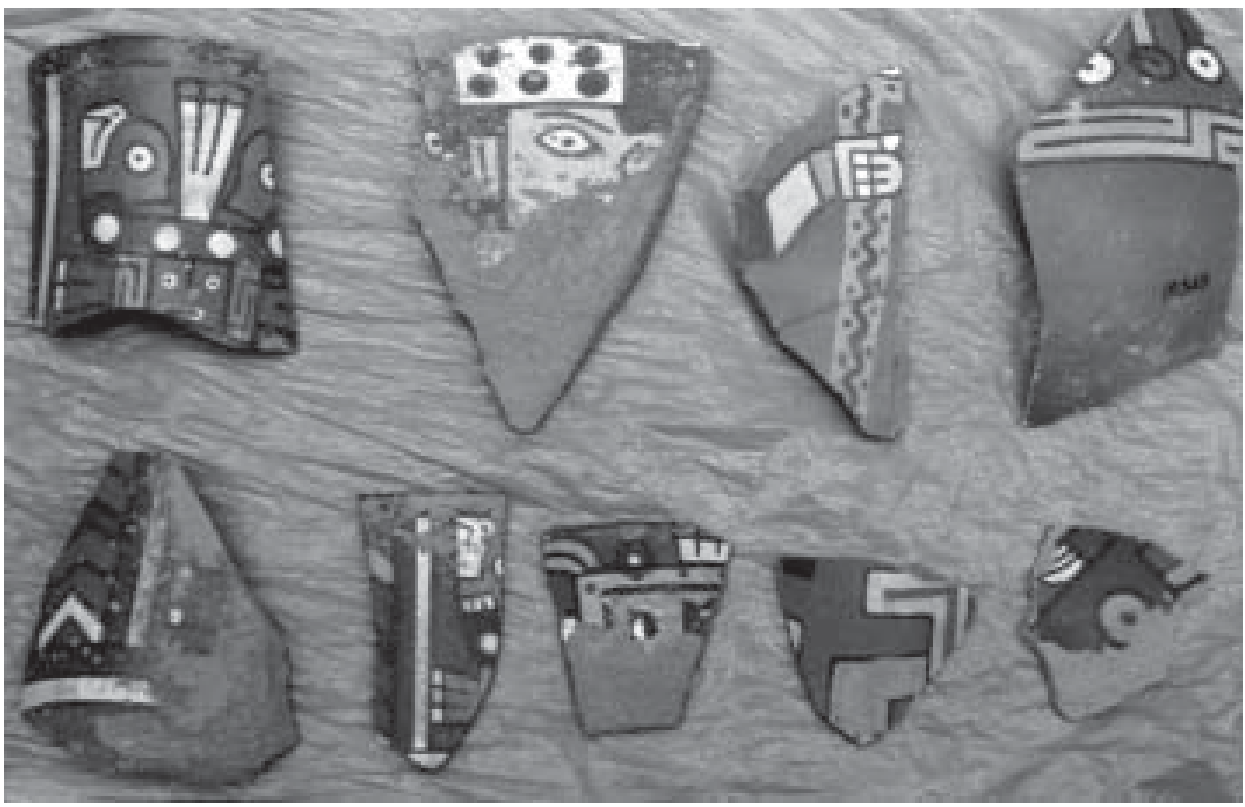

Fig. 2 - Fragmento de cerámica policroma del Horizonte Medio, encontradas en el Templo Viejo.

1985: 81-83). Esta fase corresponde a un proceso de degradación del esplendor que tuvo el viejo oráculo. Por ejemplo, los pisos de esta fase tienen un acabado rústico sin pintura. Una de las razones de esta última refacción del edificio antiguo, seguramente se debe a que el culto se centralizó en un nuevo templo construido hacia el lado oeste. Una de las pruebas del funcionamiento de ambos edificios es la comunicación entre ellas a través de un pasaje-escalinata de piedra con sus alfardas, ubicado entre la terraza norte del Templo Viejo y el frente este del Templo Pintado.

Se infiere que mientras estaba en uso la última fase del Templo Viejo, el nuevo oráculo tuvo dos fases de ocupación reflejadas en las evidencias de las graderías del frontis principal del Templo Pintado (Franco \& Paredes, 2000: 612). Una primera fase se relaciona a unas terrazas pintadas de rojo (Paredes, 1985: 73-74), con pisos policromados (rojo, blanco, verdiceleste). Una segunda fase tiene que ver con nuevas terrazas sobre las anteriores donde se repiten los motivos decorativos pintados en ocre amarillo sobre rojo y blanco sobre amarillo. Para ambas construcciones se emplearon adobitos y adobes. La presencia de adobitos en estas dos fases constructivas tiene relación con el desmantelamiento de las fachadas de los tres frentes del Templo Viejo, cuyos adobitos fueron reutilizados para el nuevo edificio.

El Templo Viejo nuevamente fue afectado por un Fenómeno de El Niño, con lluvias esporádicas que dejó huellas en la superficie del último piso, lo que desemboca en su desocupación final y en la realización de un rito de ofrenda de cerámica en los recintos importantes (Figs. 3 y 4), después de lo cual el Templo Policromado del 


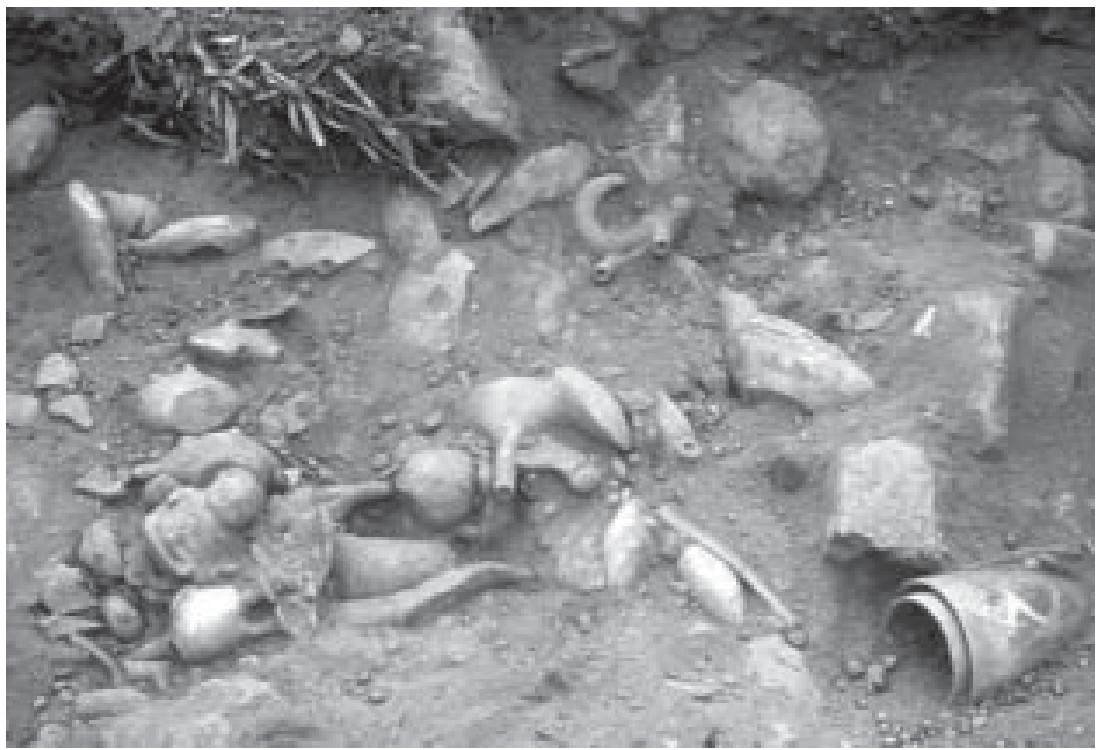

Fig. 3 - Detalle del contexto de las vasijas de cerámica escultórica tricolor de la Época 3, descubiertas en el Templo Viejo.

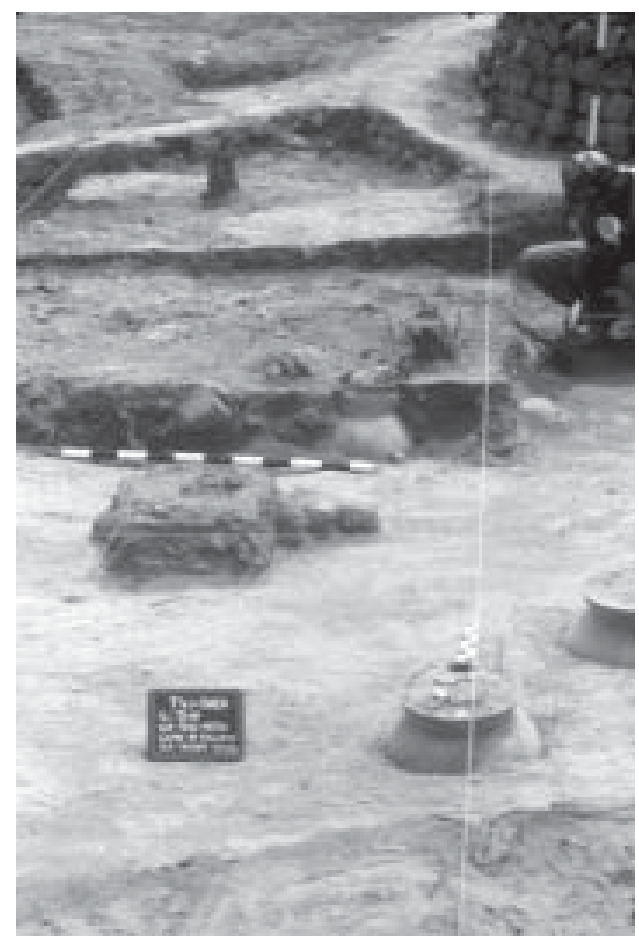

Fig. 4 - Vista parcial del proceso de excavación de los cántaros en el Templo Viejo. 
Horizonte Medio lo reemplazaría plenamente, con su consecuente crecimiento arquitectónico durante la Época 3. El abandono del viejo edificio concuerda con la fase final de la Época 3, cuando la cerámica y algunos artículos ceremoniales decaen en calidad artística, como resultado de la reducción del prestigio e influencia de Pachacamac (Menzel, 1964: 73). Se denota un aumento en la producción de artículos locales.

\section{EL TEMPLO PINTADO Y LA RESPUESTA A LA CRISIS}

El modelo de terrazas que adquiere el Templo Pintado es una influencia norteña experimentada por primera vez en el frente principal del Templo Viejo durante su última etapa de ocupación. Sin embargo, el diseño en general es una resultante de la combinación entre las formas de edificación local con las formas norteñas ampliamente conocidas (Figs. 5 y 6). Hay que tomar en cuenta que las pirámides mochicas del territorio sureño presentan el modelo de pirámides truncas con frentes escalonados y un patio superior asociado a recintos. Quizás este modelo con algunas variantes en la arquitectura de la costa central, tuvo una presencia temprana en el Grupo Tello de Cajamarquilla, donde se registra en su frontis un aterrazamiento simple con un acceso indirecto hacia un patio superior con recintos ceremoniales colindantes (Fig. 7) (Franco, 1998).

Las representaciones de la fachada del Templo Pintado fueron descritas por Uhle (1903), Muelle \& Wells (1939) y revisadas por Bonavia (1985). Considero que estas representaciones pictóricas en las terrazas estuvieron vinculadas con el restauramiento de las subsistencias agrícolas y marinas, que sin dudas tendría relación con el último meganiño que dejó huellas en el Templo Viejo. Uhle encontró en sus excavaciones un mural con la representación de una procesión de personajes humanos al parecer atados con soga. Jorge C. Muelle con Richard Wells (1939) encontraron otras representaciones con plantas de maíz, peces y aves, pintados de amarillo, rojo, rosa, gris, verde oscuro, blanco, negro, marrón y verdiceleste. Obviamente, aquí se representó los mundos terrestre y marítimo relacionados con el recuerdo de aquellas épocas de crisis, que al

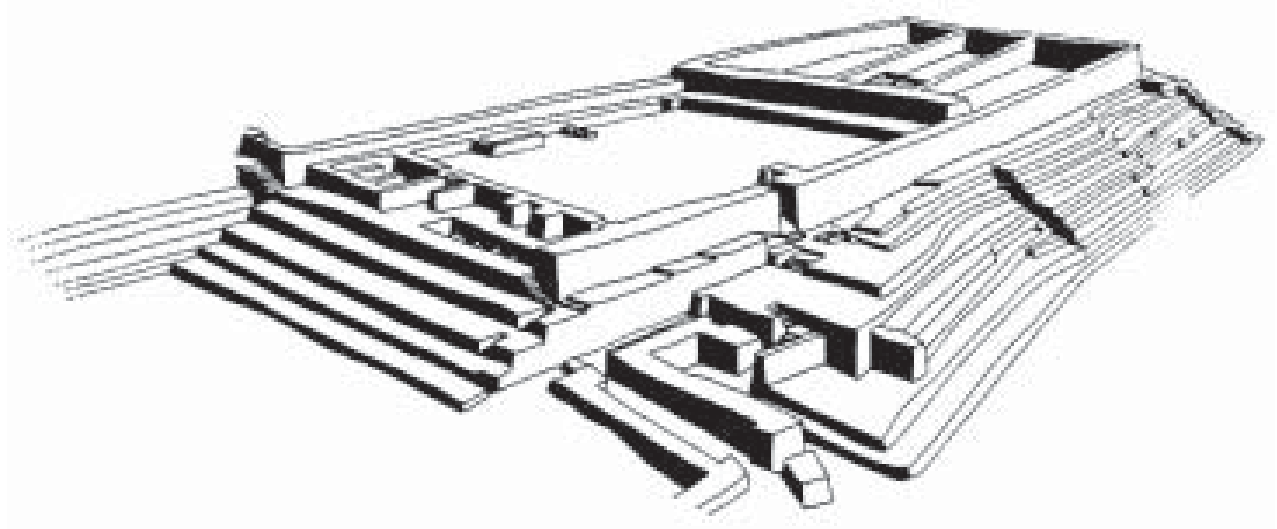

Fig. 5 - Isometría del Templo Pintado. 


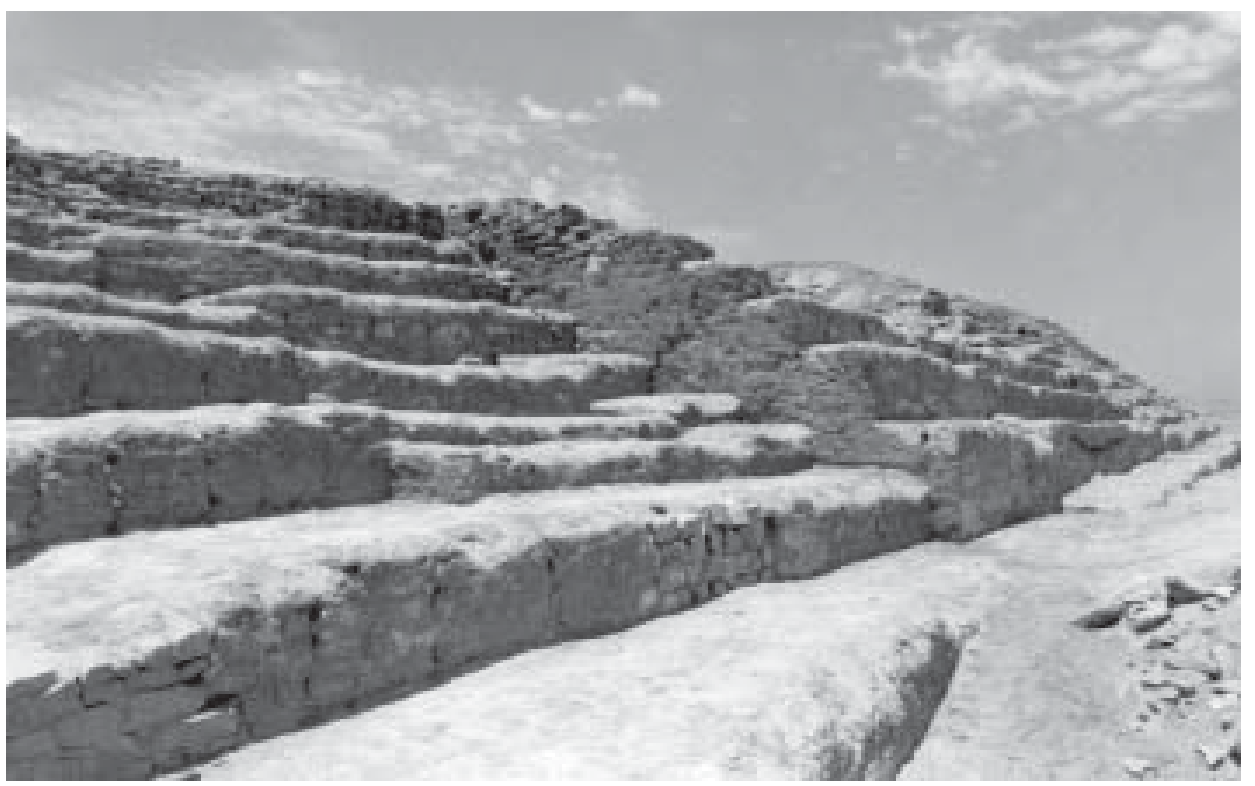

Fig. 6 - Detalle del frontis principal del Templo Pintado.

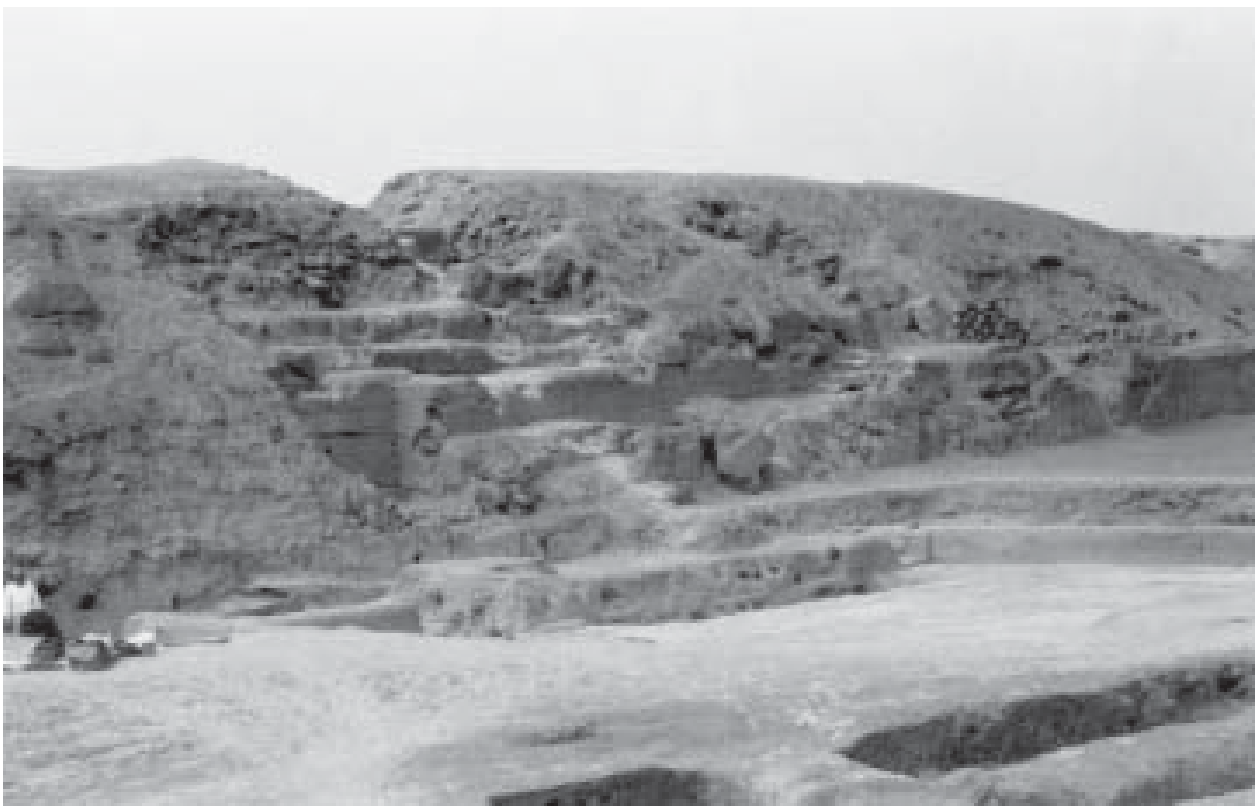

Fig. 7 - Vista parcial del frontis principal de la Pirámide Tello de Cajamarquilla. 
estar diseñados en las paredes del templo principal cumplieron una función mágicoreligiosa vinculada con el deseo de incrementar las subsistencias.

Los oficiantes del Templo Pintado subieron a la cima del Templo Viejo para realizar ritos propiciatorios con el fin de reinstaurar el orden. Dejaron una variedad de ofrendas de cerámica con formas diversas: piciformes, fitomorfos, zoomorfos, personajes libando y tocando; representaciones fitomorfas en piedra, spondylus, elevados al grado de conopas, entre otros, y finalmente sacrificaron llamas (Franco \& Paredes, 2000: 613617). Dentro de la colección de peces recuperados de la excavación, se identificaron tres especies marinas, peces sol, barrilete y palometa, que son indicadores biológicos de la penetración de lenguas oceánicas ecuatoriales hacia la costa central. El Fenómeno de El Niño posiblemente causó una fuerte sequía, debido a que los oficiantes enterraron 12 cántaros grandes en el mismo recinto de las conopas de cerámica del Templo Viejo. El estilo de los cántaros es local, pero el contexto ritual es de inspiración altoandina. Este estilo ha sido anteriormente establecido por el autor como "Ichimay tipo pintura amarillo pálido sobre color natural" (Franco, 1998: 29, 46 y 60: fig. 40). Algunas evidencias permiten plantear que cuando el Edificio Pintado estaba en funciones y el Templo Viejo abandonado, en el centro ceremonial se establecieron asentamientos de uso doméstico, cuyas evidencias permanecen debajo de las PCR. Es probable que hubo un afincamiento de grupos humanos altoandinos, que afectados por el desorden climático, emigraron de la sierra al centro ceremonial, después de lo cual las peregrinaciones al centro ceremonial se incrementaron.

En la Época 3, la imagen de Pachacamac se popularizó tanto que fue imitado en muchos artefactos suntuarios, especialmente en cerámica y madera. De esta época, se recuperó un ídolo a imitación del principal que estuvo en funciones en el Templo de Pachacamac hasta el siglo XVI y que fue derribado por los conquistadores españoles en el momento de la toma del templo, según indican los cronistas. Después de cuatro siglos, este ídolo fue recuperado por Alberto Giesecke en 1938, en las excavaciones de los escombros del frente principal del Templo Pintado o templo de Pachacamac. Existen muchas interpretaciones sobre su significado. Se ha planteado que los rostros opuestos de la parte superior se identifican con una figura siamés (Bueno, 1974-1975: 189); o que la dualidad representaría a Vichama y Pachacamac que, en un mito de creación, simbolizan el día y la noche; o que la oposición de rostros tiene relación con una divinidad masculina y otra femenina (Cf. Dulanto, 2000: 177-181). En mi opinión, se trata de una figura humano-siamesa en la que convergen íconos cosmogónicos costeños y serranos, relacionados con el maíz, mencionado en el mito de Pachacamac y Vichama (Rostworowski, 1986: 43-44). La representación de rostros opuestos sería la calificación de cualidades duales de un ser sobrenatural que fue denominado Pachacamac. Su parte inferior tiene mucho que ver con la integración del cosmos, que alude a manifestaciones del mundo celestial, en el que se aprecia al legendario ser cultural con cinturón de serpientes descendiente de Wiracocha y Aiapaec, cuyos báculos se convierten en progenitoras de plantas de maíz. Además, aparecen fenómenos estelares o luminares, vinculados con ciertos seres como el jaguar, la serpiente y el gallinazo. El arco celestial bicéfala o Vía Láctea encubre a un gallinazo, asociado al jaguar o animal lunar que simboliza la alternancia y el cambio y su relación con las pléyades o luceros y la cruz del sur (Fig. 8). Conviene recordar que las Pléyades o Cabrillas —según el testimonio 


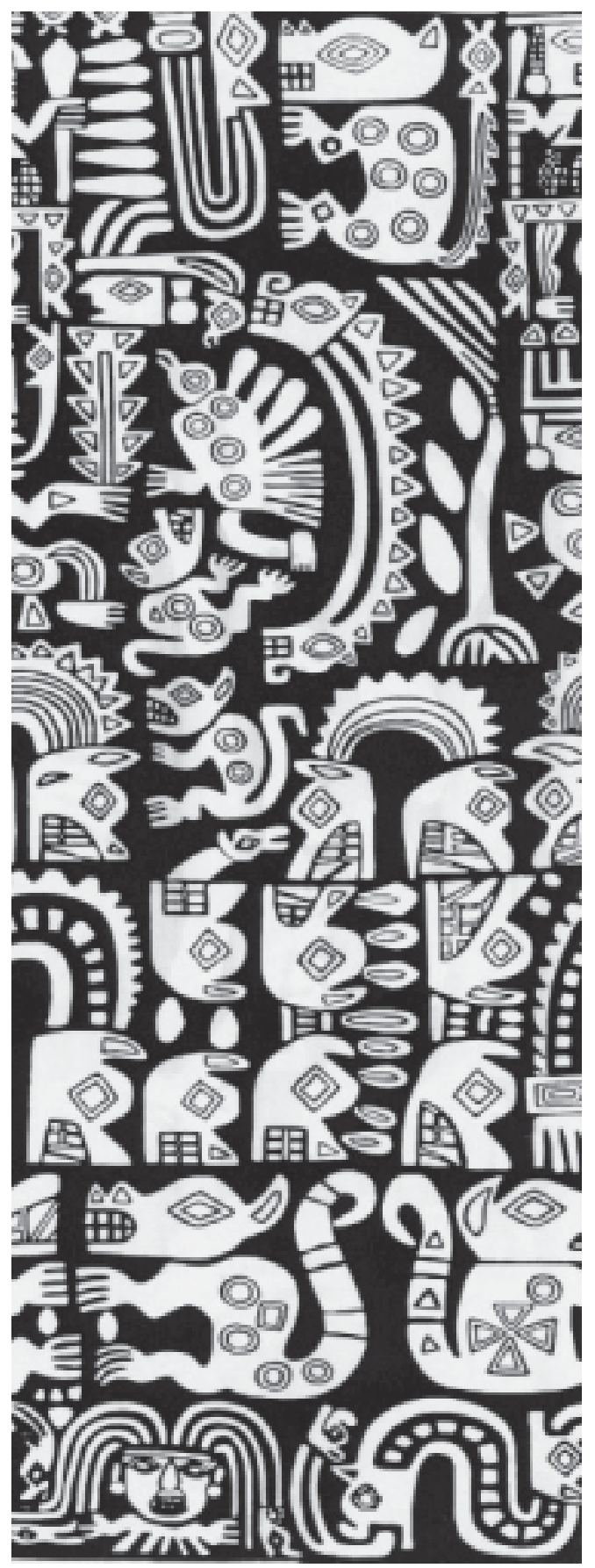

Fig. 8 - Composición iconográfica de la parte inferior del Ídolo de Pachacamac (tomado de Jiménez Borja, 1985: foto 4). 
de los cronistas- (Cobo, 1956[1653]; Calancha, 1976[1638]) eran progenitoras de la vida, encargadas de la preservación humana y del movimiento del tiempo a partir del cual se tomaba cuenta del transcurso del año, así como eran las encargadas de darles de comer y mantener sus sembríos. Por estas razones, considero que el tema iconográfico central está basado en la germinación del maíz, que ha sido el atributo esencial de Pachacamac, lo cual puede indicar en conjunto que las representaciones del ídolo asumen la función de un calendario agrícola abstracto en torno a la germinación de la planta sagrada del maíz.

Con respecto a la figuración del ídolo, hay un diseño textil de composición compleja encontrado por Uhle ( $C f$. Shimada, 1991: 43, fig. 56) (Fig. 9), al que le denomina tapestry with mithological design, en el que se aprecia a un grupo de oficiantes en torno al tótem o árbol sagrado benefactor del maíz. Al parecer, lo que se aprecia en el diseño textil, viene a ser una alegoría al ídolo principal que estaba en funciones en el Templo Pintado.

3. LA REESTRUCTURACIÓN DEL PODER RELIGIOSO Y EL SURGIMIENTO DEL CENTRO CEREMONIAL CON LAS PIRÁMIDES CON RAMPA

La presencia del desorden climático de gran magnitud geográfica instó a las sociedades costeñas a replantear muchos aspectos de su estructura religiosa y socioeconómica. La reestructuración del orden se vio como un gran movimiento de

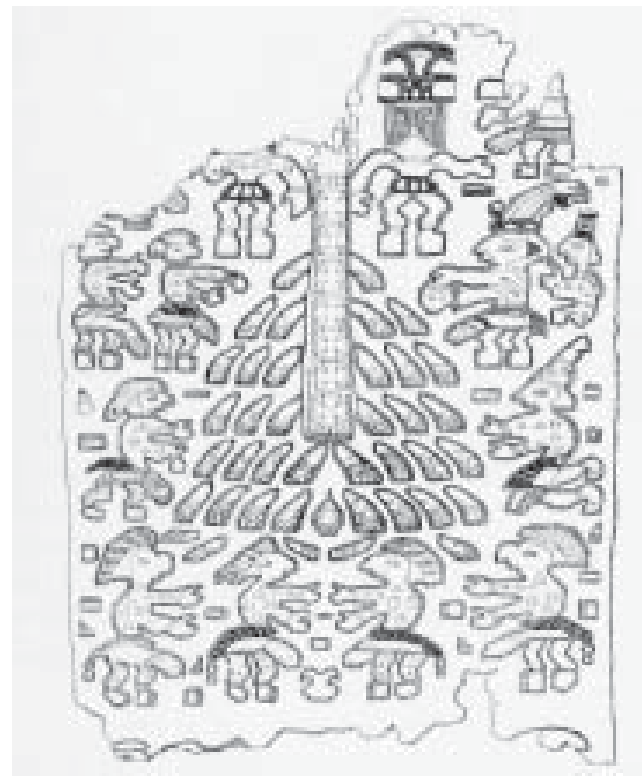

Fig. 9 - Diseño textil de una alegoría vinculada al Ídolo de Pachacamac (tomado de Uhle, 1903: fig. 56). 
reinvindicación con las fuerzas del orden en los Andes Centrales. Se plantea un esquema sui géneris en cada uno de los centros ceremoniales o cabeceras religiosas de los diferentes reinos o señoríos de la costa peruana. Las pruebas son obvias, porque a partir de esta época, surgen grandes centros ceremoniales desde Chincha hasta Lambayeque, con edificios concentrados, como Cajamarquilla en el valle medio del Rímac (Bueno, 1974-1975; Shady, 1982; Franco, 1998; Mogrovejo \& Segura, 2000), Pisquillo Chico en Chancay (Horkheimer, 1970; Bonavia, 1991), Pacatnamú en el valle de Jequetepeque (Hecker \& Hecker, 1985; Donnan \& Cook, 1986) y Túcume (Heyerdahl et al., 1996) en el valle de Lambayeque, entre los más conocidos. No está demás indicar que gran parte de los sitios mencionados tienen una ocupación anterior correspondiendo al Intermedio Temprano, lo cual respalda la importancia y prestigio religioso que tuvieron cada uno de estos sitios.

En Pachacamac se estableció una especie de confederación religiosa con la representatividad de los señoríos más prestigiosos de los valles costeños, quienes construyeron edificios muy costosos para la época. La presencia de estas unidades piramidales fue aceptada por el poder religioso central para tener presencia en el centro ceremonial y, de esta manera, mantener la unidad y armonía del señorío de Ichsmay. Obviamente esta aceptación estuvo de acuerdo con el incremento de los excedentes de producción de estos señoríos en la medida que tributaban a la deidad y al sacerdocio principal. Al respecto, Alberto Bueno (1974-1975) dice:

"los dirigentes del culto asegurábanse que los nuevos inquilinos tengan solvencia económica como para mantener regularidad en los servicios y tributación, pues detrás del culto existía una verdadera organización económica, cuyos administradores y usufructuarios eran los líderes del culto".

Cada una de las representaciones construyó sus edificios en forma paulatina, de ahí que encontramos muchas construcciones inconclusas que se quedaron postergadas. Los edificios piramidales lograron formar un trazo primigenio que creció de sur a norte, que terminó formando dos calles principales orientadas a la dirección de proveniencia de los peregrinos y tributarios (Bueno, 1974-1975: 187). La calle Norte-Sur conducía directamente a los templos principales y la calle Este-Oeste (Fig. 10) se dirigía a los sectores de Urpayhuachac, la laguna de los patos y hacia algunas huacas y construcciones frente al mar. Cada calle estaba empedrada y tenía hermosas portadas principales que conducían al interior de las pirámides con rampa (Fig. 11). Los peregrinos que transitaban por estas calles encontraban en cada esquina una guaca o un ídolo que enriquecía su fervor y su identificación con la religiosidad del sitio, según refieren las fuentes históricas. Al respecto, nosotros hemos encontrado en una esquina de la calle Este-Oeste, a unos metros antes de llegar a la portada principal de la Pirámide con Rampa $n^{\circ} 2$, un recinto pequeño de piedra que contenía una saliente de la roca madre revestido con arcilla, que simboliza la flor naciente del cerro o Apu, que como sabemos, era el símbolo de la pakarina o lugar de origen de la ancestralidad, que significaba hacer una reverencia a la montaña (Fig. 12).

Todavía queda por definir mejor quiénes fueron los que tomaron posesión de las tierras de Pachacamac para la construcción de sus edificios piramidales. Por el momento es todavía difícil de responder, a pesar de que muchos señoríos de la costa central fueron 


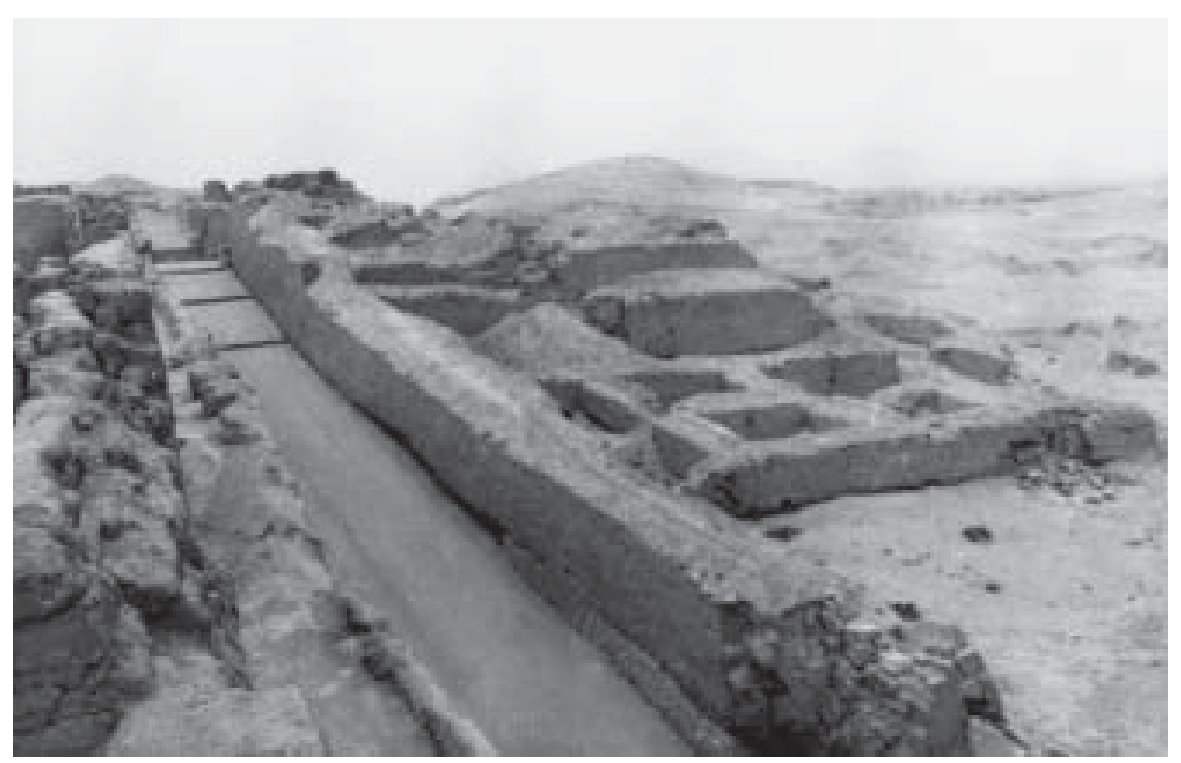

Fig. 10 - Vista general de la calle Este-Oeste de Pachacamac.

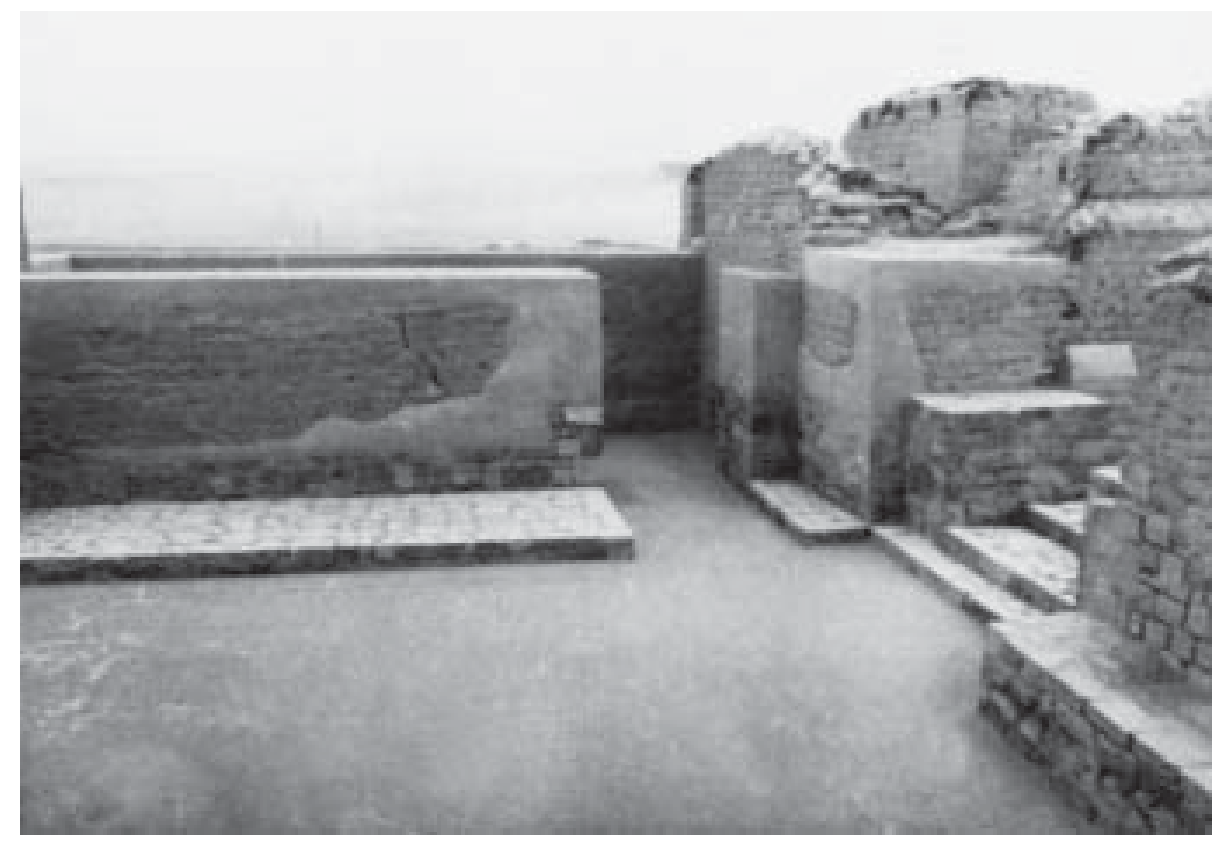

Fig. 11 - Portada principal de la Pirámide con Rampa nº 2. 


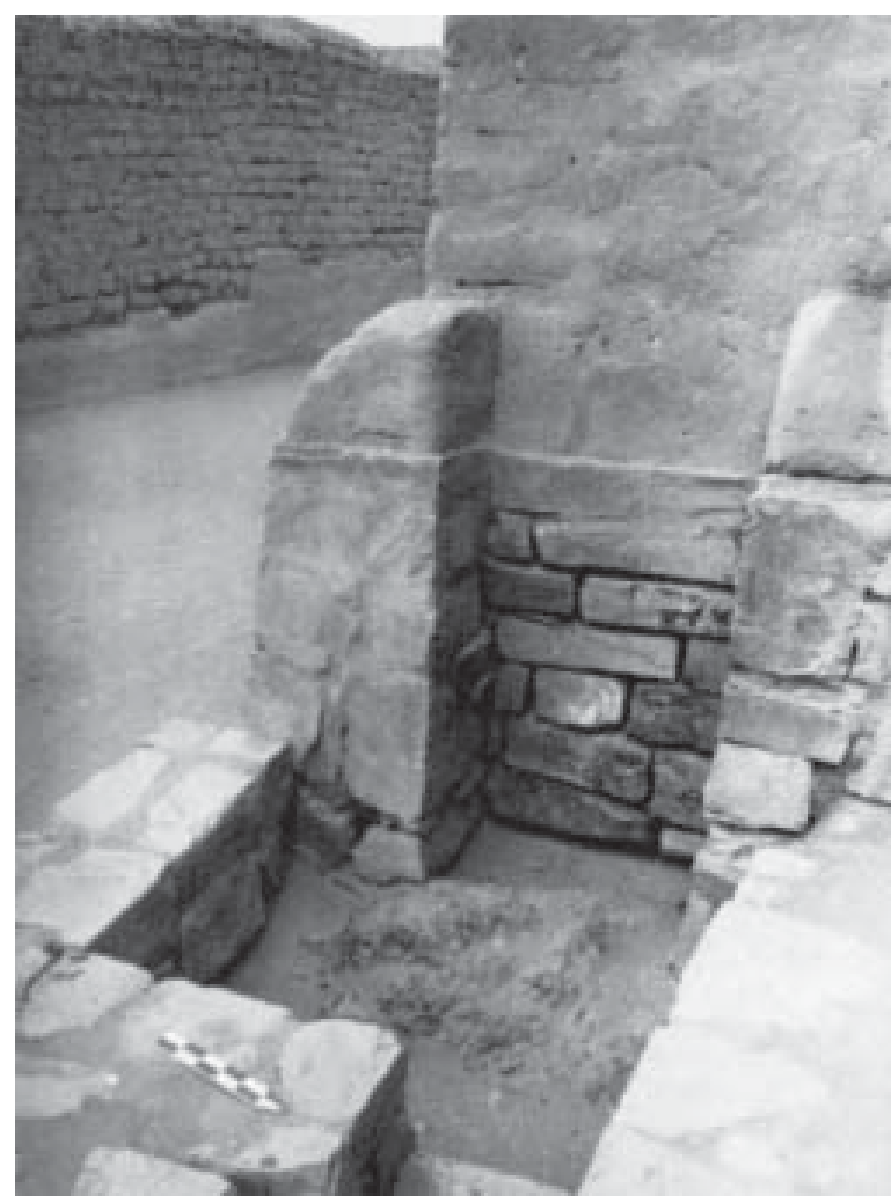

Fig. 12 - Recinto conteniendo un pequeño promontorio al cual se le rindió culto, ubicado en la calle Este-Oeste.

identificados por María Rostworowski (1977). Por lo tanto, hay razones para pensar que por lo menos los señoríos más prestigiosos del Rímac y Lurín, con cierto poder económico, tuvieron representatividad en el centro ceremonial, y uno de los elementos diagnósticos de la presencia de estos son precisamente el modelo de PCR y el patrón constructivo presentes en algunos sitios o asentamientos rurales, tales como los sitios de Pampa de las Flores, Panquilma, Tijerales y Huaycán en el valle de Lurín, últimamente estudiados por Peter Eeckhout (2003a). De otro lado, de igual manera podemos hacer un seguimiento del modelo en el valle del Rímac. Estos sitios son el complejo Armatambo (Bazán, 1992b; Díaz \& Vallejo en este volumen), Huaquerones (Bueno, 1974-1975: 188; Villacorta en este volumen) y quizás algunos sitios todavía por estudiarse que tienen este tipo de edificios. Dentro de estos sitios mencionados, hay muchas razones para pensar que Armatambo al margen de tener áreas residenciales, 
sectores ceremoniales, áreas de trabajo y cementerios (Bazán, 1992b) fue un lugar estratégico para el comercio marítimo que estuvo estrechamente vinculado con el centro ceremonial hasta épocas tardías; uno de los elementos diagnósticos es la cerámica con los estilos conocidos en Pachacamac, entre ellos las vasijas con las representaciones de sapos escultóricos unidos al borde y algunos estilos locales. Naturalmente estas y otras evidencias nos indican que entre Pachacamac y Armatambo hubo una fuerte dependencia, a tal punto que Armatambo tuvo una representatividad importante en el centro ceremonial y esta quizás podría ser la Pirámide con Rampa $n^{\circ} 2$.

El modelo de este tipo de construcciones ha sido identificado desde el valle de Lurín hasta el valle de Pacasmayo en el norte, lo que hace pensar que estos sitios tenían vinculación con el culto a Pachacamac (Jiménez Borja, 1985: 52). Uno de los sitios que puede tener mucha relación con la estructura organizativa de las PCR de Pachacamac es Pacatnamú, ubicado en la margen derecha de la desembocadura del río Jequetepeque (Donnan \& Cock, 1986). Aunque el modelo de cada PCR de Pacatnamú no es necesariamente igual a los de Pachacamac, sin embargo podemos afirmar que la estructura funcional es la misma. Por ejemplo, es interesante advertir que la composición de uno de los complejos más grandes del sitio denominado Huaca 1 (Fig. 13) tiene los componentes de volumen aterrazado con rampas centrales que se articulan a una plaza o patio delantero (Donnan \& Cock, 1986: 118, fig. 1). El edificio primigenio ha tenido una ampliación en el sector lateral de una estructura escalonada con rampas centrales, modelo que se compara relativamente con el complejo piramidal XII de Pachacamac (Eeckhout, 2003a: 154, fig. 22). Llama nuevamente nuestra atención en este caso del complejo Huaca 1 y de otros edificios de este sitio, la ausencia de áreas de vivienda o recintos de servicio, lo que es más evidente es la presencia de una buena dotación de depósitos o almacenes en el volumen principal, anexos y al interior de los cercados.

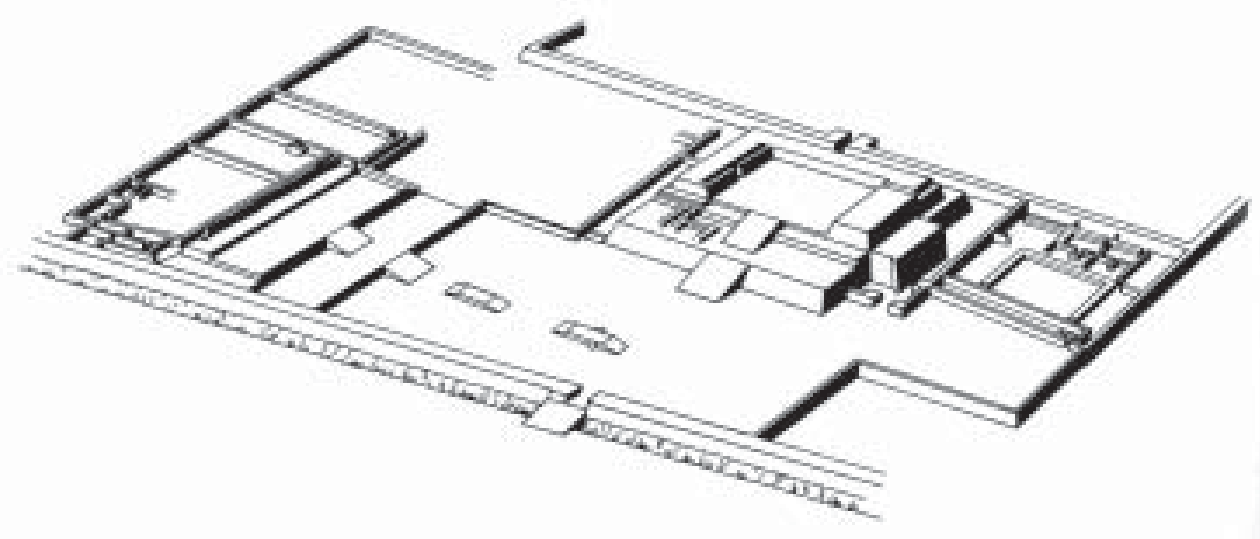

Fig. 13 - Isometría de la Huaca 1 de Pacatnamú (tomado de Donnan \& Cook, 1986: 118, Fig. 1). 
Otro elemento que ayuda a comprender la proveniencia de los peregrinos y propietarios de los edificios instalados en Pachacamac, son las portadas principales relacionadas con el interior del valle de Lurín y el camino con la costa (Bueno, 19741975; Paredes, 1991). Una de las portadas se encuentra en la tercera muralla, al noroeste, que desafortunadamente fue seccionada por la construcción de la autopista. La otra portada debió ubicarse al noreste, cerca al río Lurín, que se articulaba con un camino epimural de gran magnitud hallado en la parte posterior del pueblo Julio C. Tello de Puente de Lurín, en el sector Las Palmas, cuyo propósito era evitar transitar sobre la capa de arena. Este camino se unía a un camino real que atravesaba el valle de Lurín (Paredes \& Ramos, 1994).

Considero que no debe haber dudas sobre la naturaleza del poder en Pachacamac durante el período Intermedio Tardío, debido a que existe abundante información sobre su condición. Hay consenso que este sitio cumplió el rol de un gran centro ceremonial, cabecera religiosa del señorío de Ichimay, calificación ofrecida por muchos cronistas e investigadores (Cieza, 1986[1550]; Calancha, 1974[1638]; Bueno, 1982; Jiménez Borja, 1985; Paredes, 1991; Franco, 1998; Rostworowski, 1977; 1992; Uhle, 1903; entre otros). Pachacamac desde épocas tempranas tuvo mucha fama y prestigio, como ya lo hemos sustentado líneas arriba. Estoy de acuerdo con la definición que hace Ponciano Paredes (1988: 43) cuando discute el carácter de Pachacamac, indicando que el modelo tiene una larga tradición y que estos son centros de peregrinación y romería. Asimismo el mismo autor señala que las PCR son como

"embajadas religiosas, que poseen un patrón estereotipado que va a variar solo en su mayor o menor volumetría y en la orientación de sus rampas-ejes hacia el norte o al este con posibles implicancias astronómicas" (Paredes, 1988: 44).

Precisamente uno de los modelos de este planteamiento es la Pirámide con Rampa $\mathrm{n}^{\circ} 2$, que considero fue el edificio más prestigioso y completo de Pachacamac.

Durante el Intermedio Tardío, la religiosidad y las creencias por las divinidades protectoras, y en especial por Pachacamac, se hizo más evidente. Las peregrinaciones o romerías a este lugar santo fueron cada vez más intensas, de ahí las grandes concentraciones de edificios. Naturalmente las fiestas religiosas ofrecían un derroche de imágenes, bienes, intercambio, consumo etc. La relación de la sociedad Ichimay con los dioses tutelares se manejaba de una manera consustancial. El mercadeo de productos alimenticios, de prendas religiosas, de bienes, etc. era propio de estas celebraciones, e incluso, la producción de algunos bienes al interior de algunas PCR, llámese talleres, se justificaba en la medida que se producían para los gastos de la élite que permanecía el tiempo necesario para cumplir con los requerimientos de las ceremonias o fiestas y también para el intercambio. La meca religiosa normalmente recibía como producto de los tributos o intercambios objetos suntuarios de territorios distantes. La magnitud de basurales en Pachacamac revela una gran dinámica de festines religiosos.

Cada embajada que acudía al centro ceremonial llegaba con una comitiva completa que se instalaba en las pirámides con rampa, cuyos espacios estaban diferenciados para albergar a diferentes grupos humanos jerarquizados. El grupo de la élite se mantenía en el interior de las pirámides, mientras que el grupo relacionado con los servicios se ubicaba al interior de las canchas, donde existían espacios habitables con 
casas perecederas, y muchos espacios grandes usados como corrales para la estancia de camélidos. Lo normal en las excavaciones de las canchas que acompañan a las pirámides, es encontrar evidencias de habitación (Franco, 1998: 22- 23; Eeckhout, 2003b: 25), sendos basurales, espacios para secar alimentos (Jiménez Borja, 1985: 42), espacios para mercadear y una gran dotación de depósitos que fueron incrementándose en la medida que los líderes de cada conjunto tenían mayor riqueza. Este modelo de canchas con depósitos en crecimiento puede observarse en todos los centros religiosos conocidos como Túcume, Pacatnamú, Chan Chan, Cajamarquilla y otros. Las pirámides estaban regentadas por los señoríos más prestigiosos de la nación de Ichimay.

Últimamente Peter Eeckhout (1999; 2003a: 168-169; 2003b: 24-25) ha planteado algunas hipótesis contrastables sobre el carácter de las PCR en Pachacamac, en el que se identifica cada PCR como el palacio de un rey que ocupa el edificio durante su vida y tiene el control de la producción agropecuaria, la fuerza de trabajo local, la pesca y el comercio marítimo. Según el autor, a su muerte había una sucesión dinástica, dando preferencia a la construcción de otro edificio, al igual que el modelo Inca. Además, Eeckhout dice que los palacios fueron la morada final de estos señores principales. Considero que estos argumentos señalados por Peter Eeckhout serían interesantes en la medida en que el centro ceremonial hubiera sido sustituido por un centro urbano o una ciudad donde el poder económico, religioso, la producción y los servicios públicos hubieran estado concentrados, de tal manera que los señores principales ocuparían en forma doméstica las pirámides con rampa. Esto me hace pensar, más bien, en un modelo poco probable, porque solamente si contrastamos las 14 pirámides registradas por el mismo autor y consideradas como palacios, la gran mayoría de estos immuebles no estan habilitados para residencias permanentes. Hay una enorme contradicción entre el número de espacios de uso humano con el número excesivo de depósitos en cada unidad piramidal. Muchas están dotadas de almacenes antes que de espacios residenciales y además son construcciones inconclusas que no completaron el modelo de las Pirámides con Rampa $n^{\circ} 1$ y 2 para referirnos en forma especial. No hay entonces evidencias convincentes para tal afirmación. La sucesión dinástica del uso religioso de estos edificios puede tener relación con el número de remodelaciones como la Pirámide ${ }^{\circ} 2$ (Franco, 1998) y quizás con la ampliación de algunos edificios adjuntos —empleando el mismo modelo - de menor capacidad para el heredero, tal como vemos en muchos edificios, especialmente en los complejos piramidales II, III, VII, IX y XII, que han sido muy bien registrados por Peter Eeckhout (2003a: 152-155).

Hay una cita que debemos tomar en cuenta, porque considero que se ajusta al uso de las pirámides con rampa en Pachacamac, planteado por el Agustino Antonio de la Calancha (1974[1638]), cuando decía que estos edificios son

“... altares de particulares familias, pueblos, reynos; provincias, que como capillas que adornan i hazen autoridad a una de nuestras catedrales...".

Según esta referencia citada, da la impresión que Calancha trata de forzar su propuesta con términos propios, sin embargo, el concepto de la organización y función de las pirámides estaba basado en este modelo esbozado por el cronista y que dicho modelo se ajusta a las evidencias encontradas en las pirámides más conocidas. 
Con las evidencias encontradas en las PCR, principalmente en la $\mathrm{n}^{\circ} 2$, podemos afirmar que uno de los propósitos de estos edificios piramidales fue acumular riqueza basado en mayores bienes para los gastos del culto particular que se realizaban al interior de cada edificio, para tributar a la deidad central instalada en el templo principal y particularmente para el comercio en las celebraciones centrales. Este es un modelo sui géneris que todavía sobrevive en los Andes. Sabemos que en los depósitos se acumulaban ají, algodón, maíz, mates, etc. (Cf. Franco, 1998: 19), como los hallazgos de la Pirámide con Rampa $\mathrm{n}^{\circ}$ 2, que en la época Inca eran administrados mediante los kipus, una forma de administración que seguramente viene desde épocas anteriores.

Una pregunta interesante es ¿dónde se realizaban las celebraciones particulares y centrales vinculadas con la deidad principal? Hay suficientes datos que indican que las celebraciones religiosas particulares se realizaban en los patios principales de las PCR, y si no habían patios definidos, se realizaban al interior de algunas canchas o cercados. De otro lado, las celebraciones centrales obviamente se habrían realizado en un espacio abierto o plaza ubicado frente al Templo de Pachacamac, donde hay ausencia de edificios monumentales, los cuales más bien, fueron trazados más al norte. Este espacio santo seguramente fue ampliado en la época Inca con mayores construcciones, el cual ha sido considerado como la Plaza de los Peregrinos. En un principio quizás este espacio fue abierto y en un segundo momento fue amurallado, para separar el área del cementerio que empezó a crecer desmesuradamente de sur a norte a partir de la Época 3, como ha sido demostrado con las excavaciones de Uhle (1903).

Hasta el momento se han excavado tres PCR en Pachacamac (Jiménez Borja, 1985; Paredes \& Franco, 1987; Paredes, 1988; Franco, 1998; Eeckhout, 1999; 2000; 2003a y 2003b). La primera fue excavada entre 1958 y 1960 por el Dr. Arturo Jiménez Borja; la segunda pirámide fue excavada entre 1981 y 1983 por Ponciano Paredes y el autor, y la tercera pirámide fue excavada a partir de 1993 por Peter Eeckhout. Estas tres pirámides sirven de modelo para una discusión sobre la función y organización de estas unidades arquitectónicas, propuesta que alcanzaremos tomando en cuenta muchos aspectos de la excavación de los interiores. El resto de las pirámides aún no han sido excavado integralmente, pero a la fecha conocemos algunos comentarios, levantamientos planimétricos realizados por Peter Eeckhout (2003a: 149-155) y cateos de prospección que aún no se han reportado (comunicación personal P. Eeckhout, 2004), que seguramente permitirán a futuro hacer algunas comparaciones y propuestas interesantes sobre las relaciones arquitectónicas entre las pirámides.

La primera pirámide denominada n 1 o "JB" (Fig. 14), no ha sido debidamente investigada y lo único que ha quedado son algunas notas de campo otorgadas por Jorge Zegarra Galdos, asistente de campo de Arturo Jiménez Borja. Ciertamente el objetivo de la excavación de este tiempo fue limpiar la pirámide para mostrarla al público, de ahí que carecemos de información de campo. Esta pirámide tiene un eje de orientación al Noroeste, aunque también inconclusa, pero es a la fecha la que tiene mayores espacios arquitectónicos comparables con la Pirámide $\mathrm{n}^{\mathrm{o}} 2$ y cumple el modelo de volumen elevado, patio delantero, patio posterior y almacenes (Fig. 15). Lo particular de esta pirámide es que tiene un modelo adjunto de volumen elevado, rampa y plaza delantera, que la hace comparable con los conjuntos piramidales VII y IX ( $C f$. Eeckhout, 2003a: 


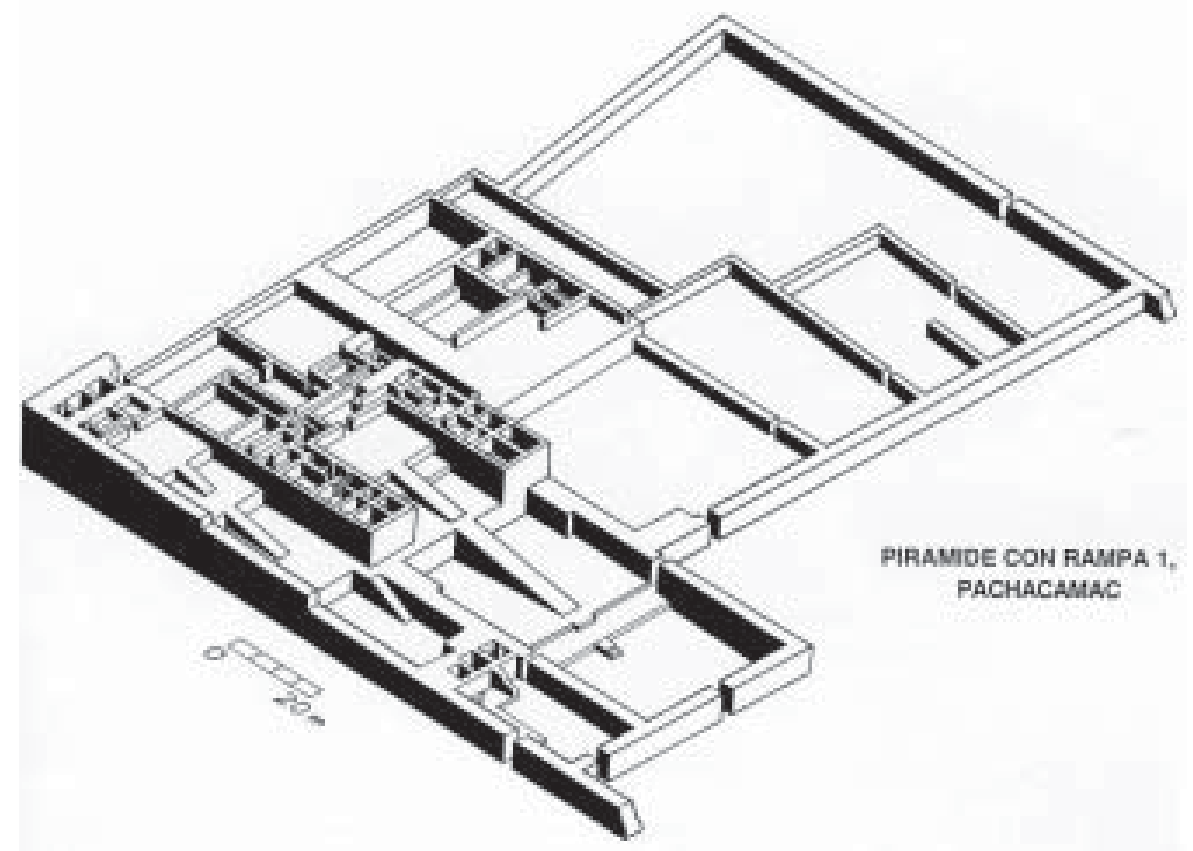

Fig. 14 - Isometría de la Pirámide con Rampa nº 1 (levantado por el autor, 1985).

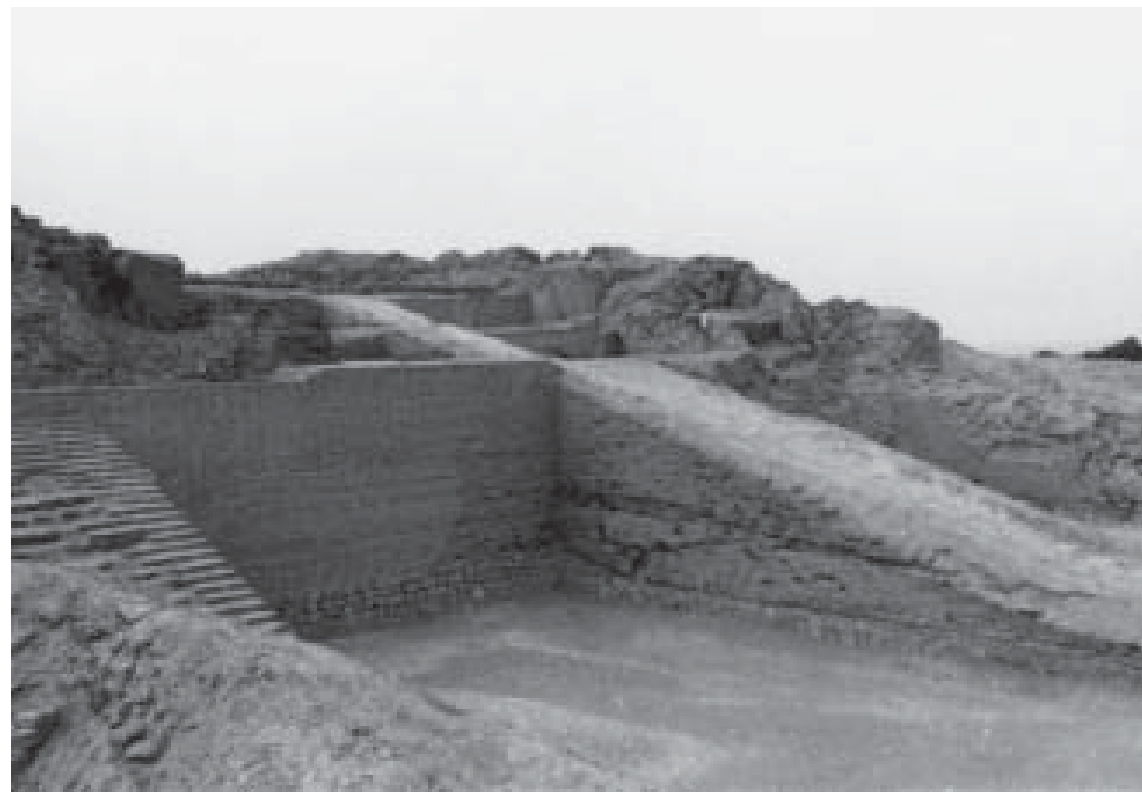

Fig. 15 - Vista parcial del patio y volumen de la Pirámide con Rampa no 1. 
153, figs. 18 y 20). La presencia de un taller de cerámica y secadero en su patio anexo (Fig. 16) (Jiménez Borja, 1985: 42) la hace comparable con las evidencias de áreas para secar cerámica precocida encontrada en el patio principal de la Pirámide no 2 (Franco, 1998: 40-42). En los patios delantero y posterior y alrededores se encontraron grandes acumulaciones de basura con material Inca, que revela el estado de abandono o desocupación del edificio antes del arribo de los conquistadores. Dentro de los montículos de basura se recuperaron numerosos fragmentos de cerámica retratando a los señores principales que ocuparon la pirámide; también se recuperaron figurinas, colgajos, representaciones de monos, perros, loros y otras mascotas que seguramente acompañaron al señor principal, cerámica ceremonial marrón sobre crema con representaciones de sapos escultóricos y otras representaciones vinculadas con el culto central. Aunque no hay resultados cronológicos para este edificio, se puede deducir que tiene pocas remodelaciones, lo cual sugiere que este edificio es uno de los más tardíos con relación a los otros. Es probable que su uso se haya establecido al poco tiempo de la llegada de los incas a Pachacamac. Al igual que la Pirámide ${ }^{\circ} 2$, el uso que se le dio a este edificio en la época Inca fue quizás de mayor permanencia que durante el periodo Intermedio Tardío, que finalmente fue abandonado y tugurizado con grandes acumulaciones de basura.

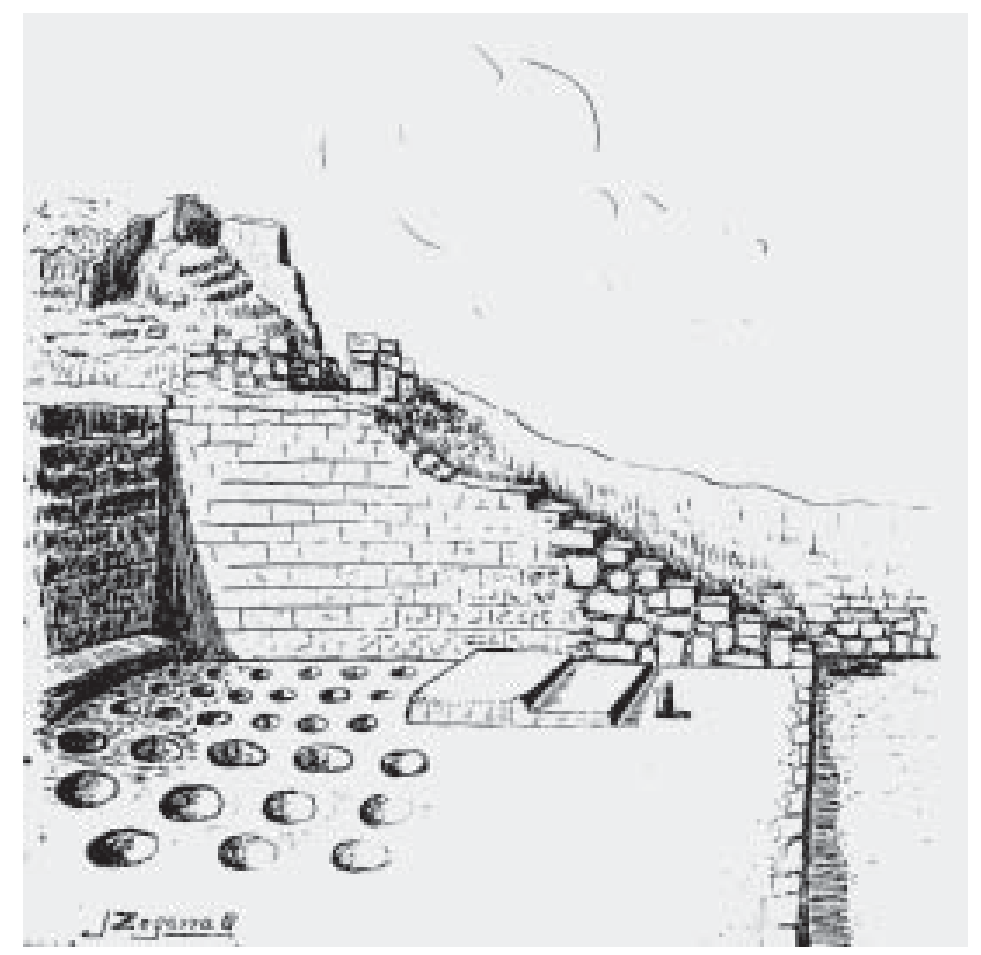

Fig. 16 - Dibujo de una de las áreas de producción y secado de cerámica en la Pirámide con Rampa no 1 (elaborado por Jorge Zegarra Galdos, 1961). 
La tercera pirámide denominada $\mathrm{n}^{\circ} 3$ (Fig. 17), ha sido estudiada por Peter Eeckhout (1995; 1999; 2003a y 2003b). Es un edificio ubicado sobre un promontorio rocoso al este de la Pirámide $n^{\circ} 2$, desde el cual se obtiene una vista completa del centro ceremonial. Su autor llega a indicar que todos los datos de campo en varios sectores conducen hacia una función ritual, debido a numerosas ofrendas de sacrificios de animales, textiles y algunos entierros, entre los cuales se incluye la de un niño y una mujer adulta con un mono; correspondiendo todos ellos a la fundación del edificio (Eeckhout, 2003: 163). Las investigaciones del mismo autor llegan a establecer tres ocupaciones que tienen relación con el crecimiento del edificio, cuyos fechados oscilan entre 1390 D.C. hasta 1460-1470 D.C., según las calibraciones realizadas ( $C f$. Eeckhout, 2000: 233, 241; Michczynski et al., 2003). De acuerdo al conjunto arquitectónico se tratarían de tres pirámides con rampa (pirámides A, B, C), que corresponden a diferentes momentos de ocupación, siendo la pirámide B la más antigua. De otro lado, se deduce que hay un primer edificio pequeño orientado al Este, que presenta el modelo de volumen, plaza delantera y depósitos anexos, con un acceso principal hacia la esquina sureste de su patio. Posteriormente se establece un nuevo edificio anexo de mayor magnitud orientado al Norte, con un acceso principal hacia el Este ( $C f$. Eeckhout, 1999: 188-192). Hay un crecimiento final hacia el Oeste, con el establecimiento de una pequeña pirámide con rampa lateral y patio delantero que tiene en su volumen depósitos

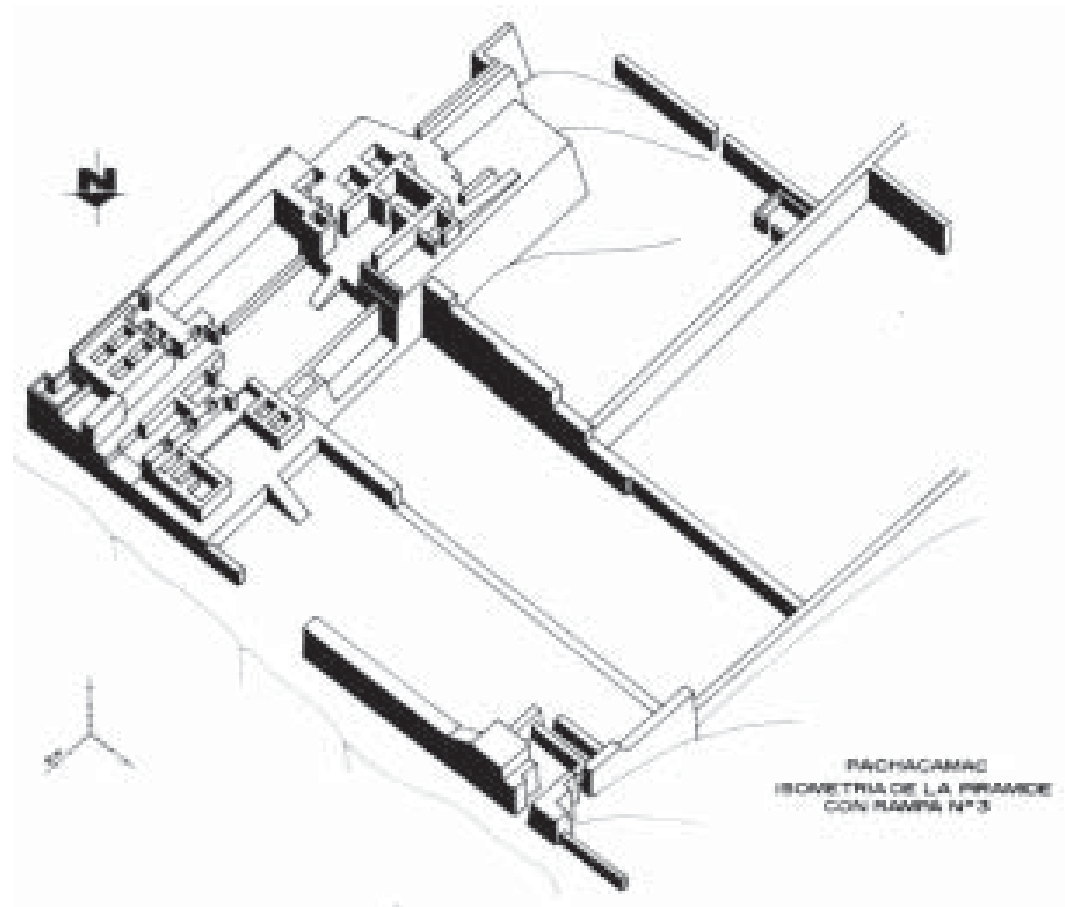

Fig. 17 - Isometría de la Pirámide con Rampa no 3 (levantado por el autor). 
en forma de colmena. Llama mucho la atención la ausencia de recintos de habitación en estas tres pirámides del mismo conjunto, lo que hace notar que gran parte de los espacios cerrados están preferentemente vinculados con depósitos o almacenes. Una vez más eso reitera la propuesta de que el propósito de estos edificios fue aprovisionar bienes antes que estos espacios sirvieran para ocuparlos en forma doméstica o permanente. Considero por eso y otros motivos, aun cuando lo mismo se ve en la mayor parte de conjuntos piramidales, que estos edificios estuvieron para acumular los excedentes de producción de las élites que tenían representatividad en el centro ceremonial.

Las excavaciones en una plaza amplia ubicada entre el edificio C y B (Eeckhout, 1995), revelaron algunos hallazgos que señalan que este espacio sirvió para la realización de eventos ceremoniales importantes que tenía como centro un estrado con rampa orientado al Oeste. Eeckhout señala que hubo ocupaciones más tempranas anteriores a las pirámides, que indican una ocupación doméstica con cerámica atribuible al Horizonte Medio Tardío que considero serían contemporáneas con las evidencias encontradas en los sustratos de la Pirámide con Rampa nº 2 .

\section{LA PIRÁMIDE CON RAMPA No 2 COMO MODELO DE INTERPRETACIÓN}

En los años de 1981-1983, bajo la dirección de Ponciano Paredes, se excavó la Pirámide $n^{\circ} 2$ (Figs. 18 y 19) gracias a la gestión del Dr. Arturo Jiménez Borja y el apoyo económico de Cooperación Popular, durante el gobierno del Presidente del Perú Fernando Belaúnde Terry. Las investigaciones en este inmueble permitieron discutir la forma o el modelo y sus espacios ceremoniales, luego de lo cual se consideró que este edificio con relación a sus similares fue el de mayor prestigio e importancia para su tiempo, debido al mayor esfuerzo arquitectónico en su diseño.

Su portada principal es muy bella y su acceso es por la calle Este-Oeste. Antes de ingresar hubo una banqueta para el descanso de los peregrinos con sus provisiones que llegaban al sitio después de un largo viaje. Sobre una plataforma alta, estaban seguramente los guardianes que cuidaban el edificio y estaban a la expectativa de quienes a menudo transitaban por la calle.

En la época de las celebraciones religiosas, las familias o clanes seguramente ingresaban al interior del edificio sorteando algunos ambientes y pasajes, que era una forma de prepararlos espiritualmente antes de tomar contacto con los espacios sagrados del interior. En la actualidad nos ocurre algo similar, cuando atravesamos el primer sector de acceso, de pronto aparece un marco arquitectónico sobrecogedor, constituido por el patio, la rampa principal y el volumen piramidal. Realmente es una vista impresionante.

Nuestras excavaciones (Paredes \& Franco, 1985; Franco, 1998) revelaron que en el patio se veneraban a ídolos y se realizaban libaciones y banquetes que formaban parte de los ritos propiciatorios a las divinidades del agua, ritos para el bienestar de la agricultura y para el incremento de las subsistencias marinas. Las pruebas en este espacio ceremonial o patio son grandes acumulaciones de basura conteniendo restos de 


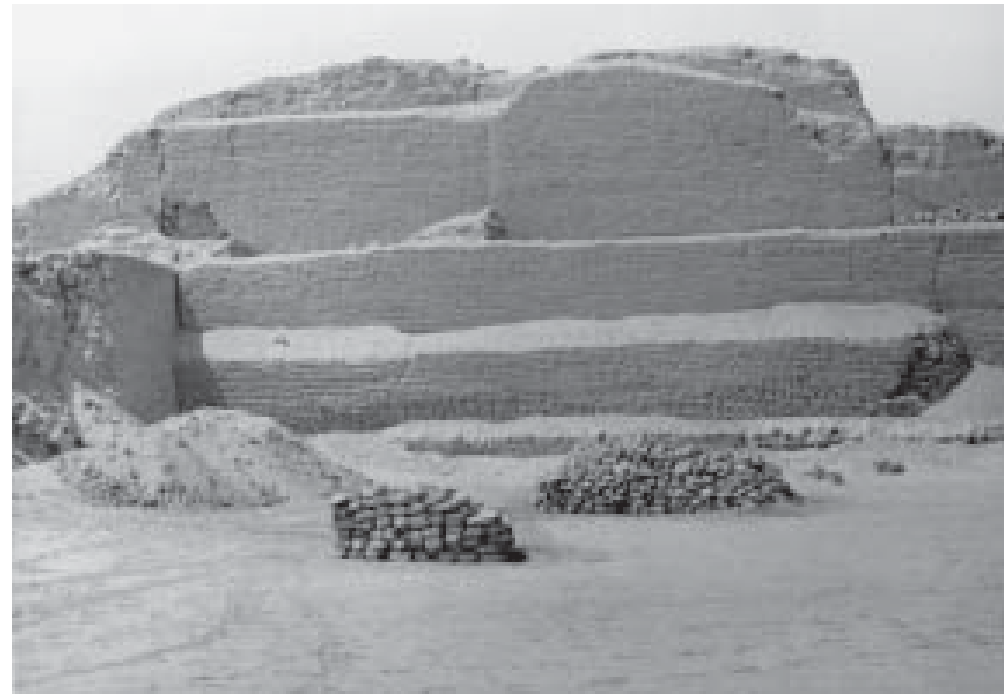

Fig. 18 - Frente norte de la Pirámide con Rampa no 2.

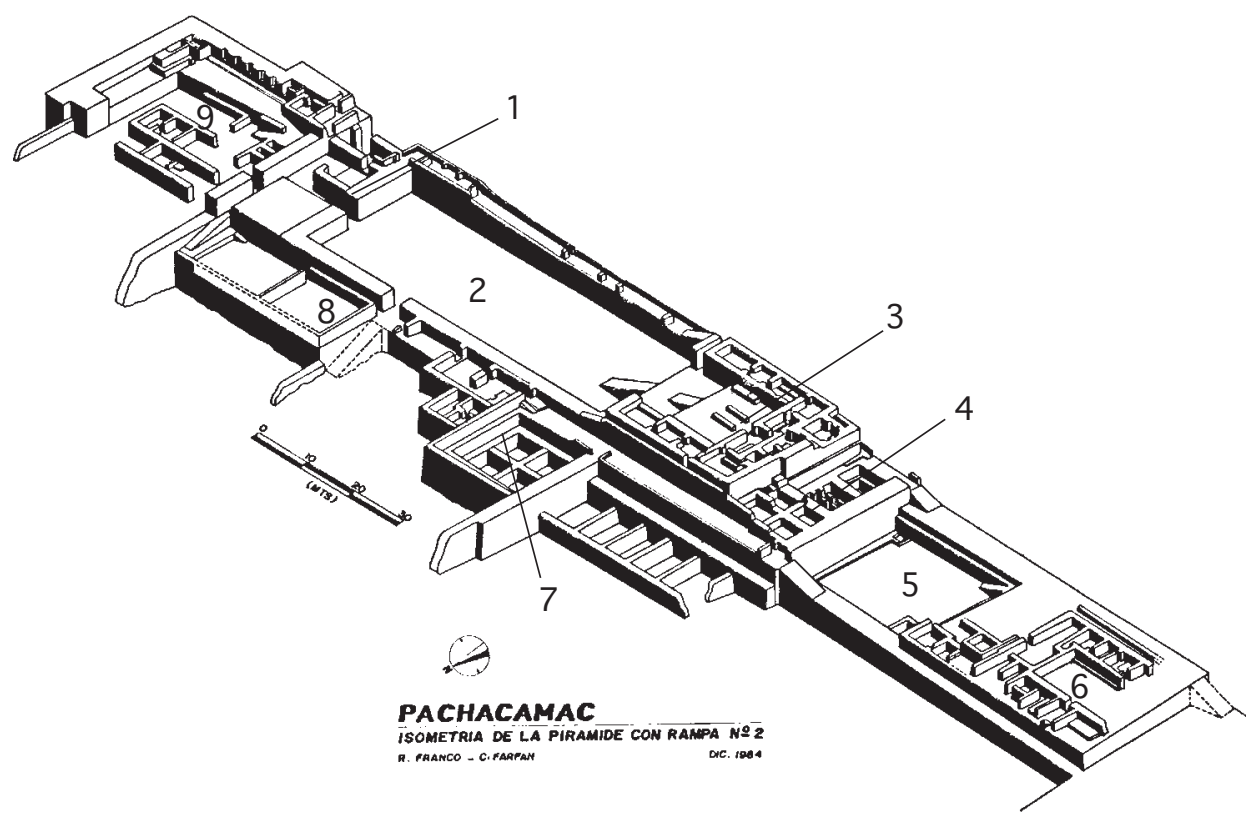

Fig. 19 - Isometría de la Pirámide con Rampa no 2 (levantado por Carlos Farfán y el autor, 1984). 1. Ingreso principal (sector I); 2. Patio principal (sector II); 3. Volumen aterrazado (sector III); 4. Depósitos posteriores (sector IV); 5. Patio adicional hundido (sector V); 6. Áreas de viviendas (sector VI); 7. Depósitos y recintos laterales (sector VII); 8. Recintos laterales (sector VIII); 9. Área ceremonial y de vivienda (sector IX). 
comida y cientos de fragmentos de vasijas de cerámica que tenían como particularidad la presencia de sapos escultóricos o aves marinas sujetados a los bordes. Asimismo, se demostró que antes de la llegada de los incas, el patio fue también un espacio designado para actividades artesanales vinculadas con la producción de textiles (Fig. 20), metales y tardíamente para la producción de cerámica.

Pasando el patio hay una gran rampa que conduce a una elevación piramidal o aterrazamiento, donde se concentraba y se dirigían las actividades ceremoniales (Fig. 21). Este es un espacio central a modo de auditorio, rodeado de recintos especiales con hornacinas para contener imágenes de culto y banquetas que servían obviamente para el pernocte del líder del culto (Fig. 22) y algunos oficiantes que permanecían el tiempo que duraban las celebraciones. Hacia el Suroeste se ubicó una cámara funeraria con nicho interior que desafortunadamente fue saqueada totalmente. Esta cámara fue la tumba del líder religioso. El espacio central formado por recintos que conforman una "U" orientada al Este, fue el escenario de las actividades rituales, el cual presentaba dos columnatas de adobe que soportaban un techo horizontal construido con cañas amarradas con soguillas de totora y revestida con barro y formaba un acceso central dirigido al recinto mayor. De otro lado, este espacio a modo de auditorio, tenía banquetas finas hacia los muros norte y sur que sirvieron para la colocación de algunos artículos que se

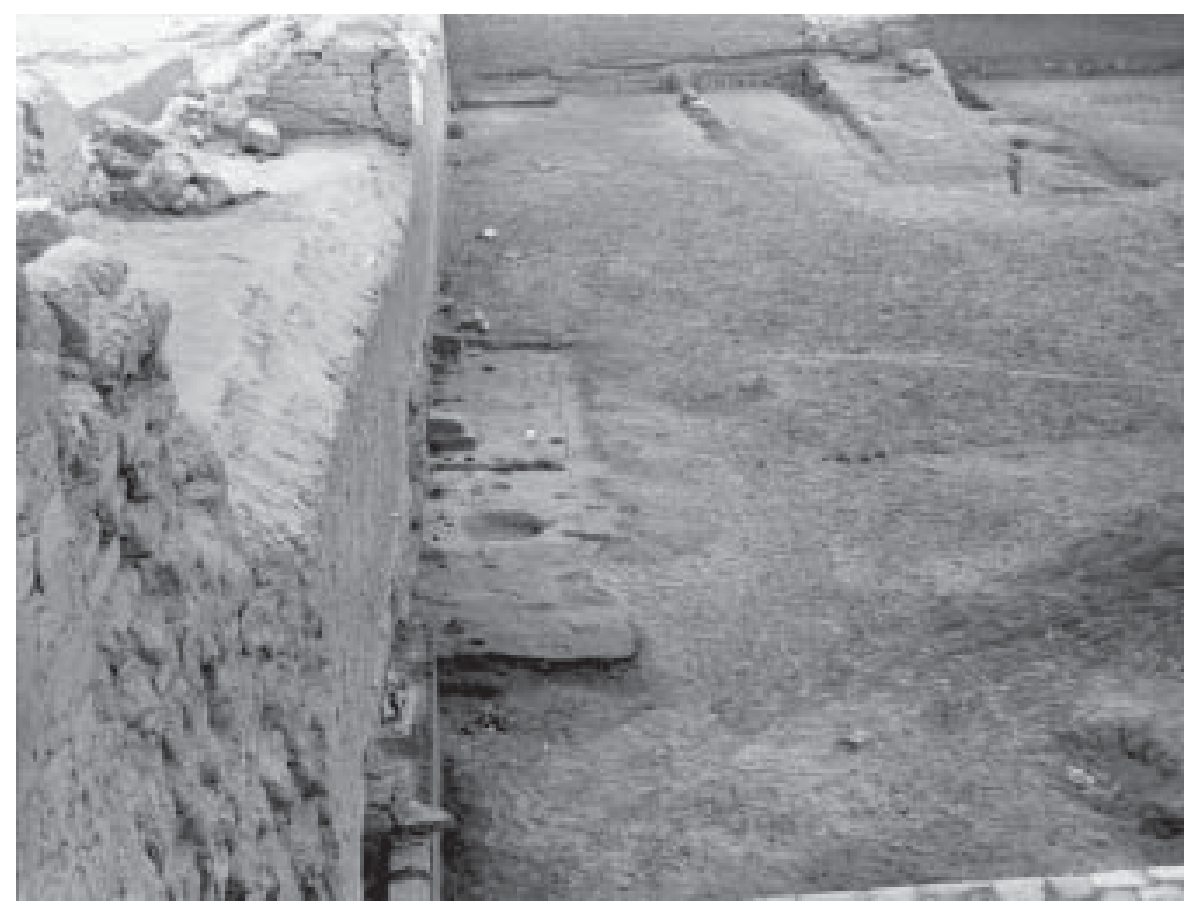

Fig. 20 - Vista parcial del patio principal de la Pirámide con Rampa no 2, donde se aprecian las excavaciones de un sector vinculado con la producción textil. 


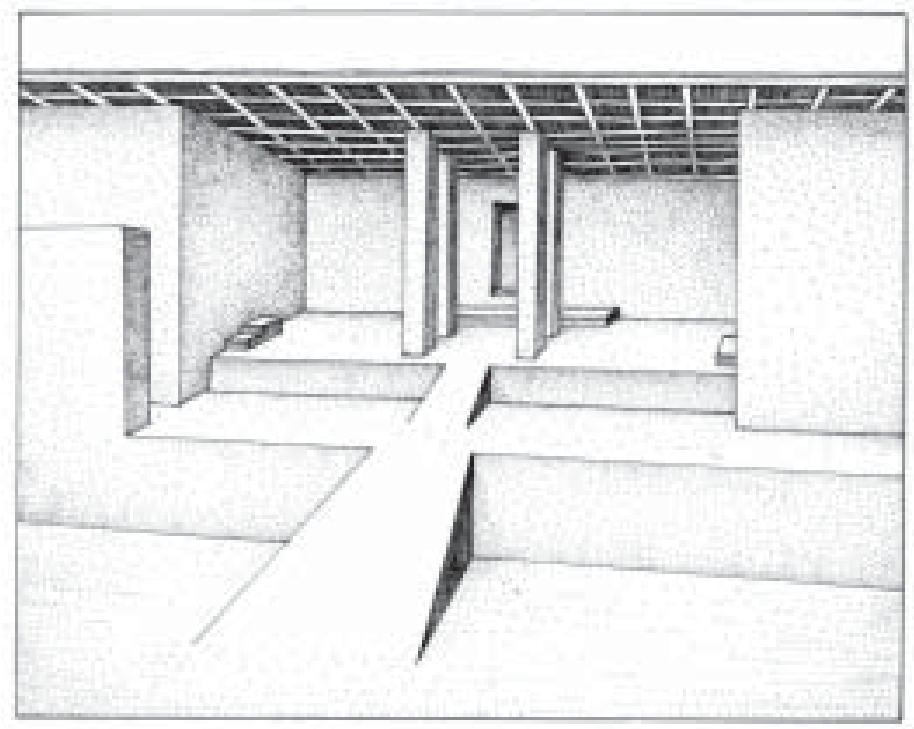

Fig. 21 - Reconstrucción hipotética del sector ceremonial (sector III) de la Pirámide con $\operatorname{Rampa}^{\circ} 2$.

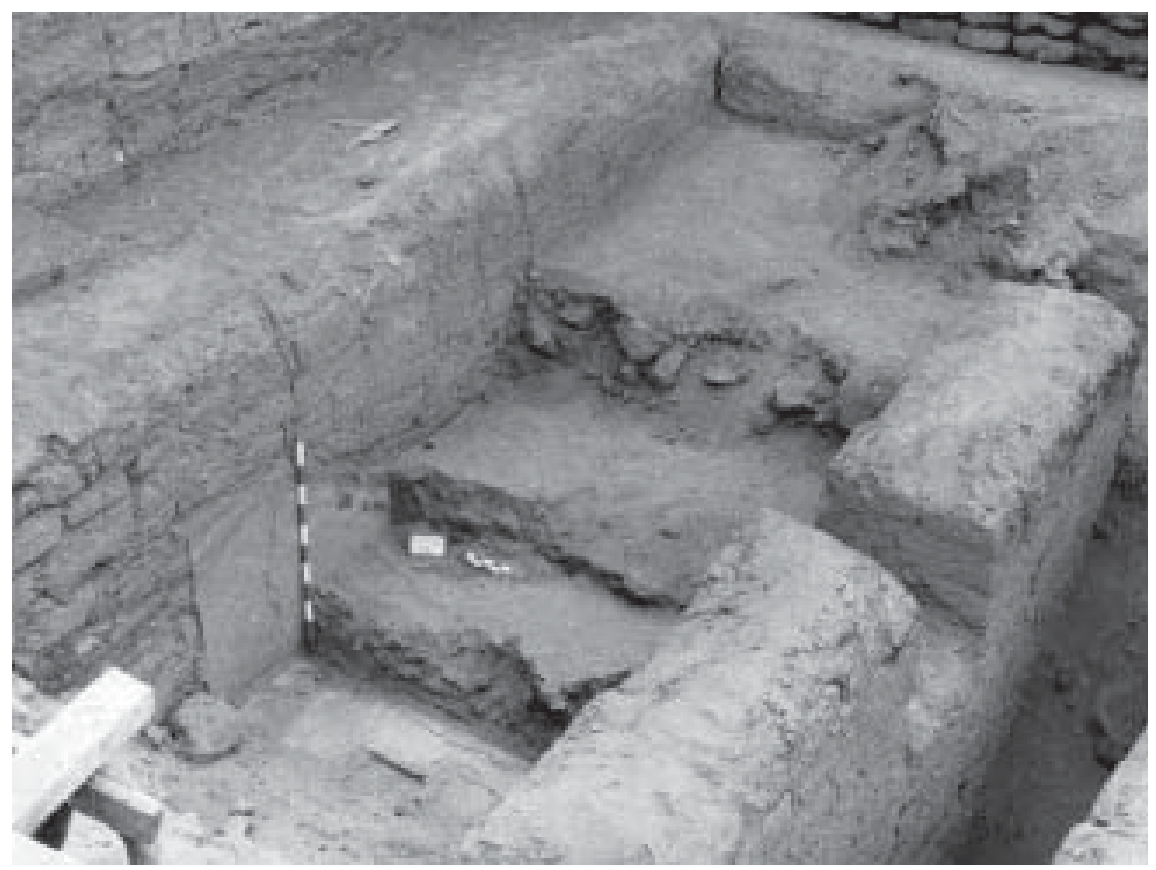

Fig. 22 - Uno de los depósitos que contenía ají en la parte posterior del volumen piramidal. 
empleaban en la ceremonia. De otro modo, podríamos indicar que este sector funcionó como una plataforma ceremonial donde se ejecutaba todo el programa religioso en presencia de una multitud de peregrinos apostados en el patio delantero. Este sector medular de la pirámide estaba intercomunicado directamente con unos depósitos que estaban ubicados en la parte posterior, que en un momento determinado estuvieron abastecidos de ají, maíz, mates, etc. los cuales fueron conservados con arena seca de río (Fig. 23). El acceso directo del volumen piramidal a estos depósitos hace sospechar que los líderes del culto usaban estos productos almacenados para su consumo y comercio con sus vecinos instalados en otras pirámides. Estos líderes religiosos tenían también acceso a otros sectores de la pirámide para desarrollar sus oficios con relación a otras celebraciones o acontecimientos religiosos. Por ejemplo, uno de los epimurales del patio conducía a un espacio destinado para el culto a los muertos (Fig. 24) ubicado al este del edificio. Se caracterizaba por tener una terraza elevada orientada al Norte con cinco nichos que servían para contener quizás los cuerpos momificados o Mallquis de los señores principales a quienes se les rendía culto y un pequeño compartimiento adjunto que se utilizó para guardar la parafernalia funeraria y para otras necesidades. Sobre la misma terraza, hay unos depósitos donde se almacenaban los tributos conferidos a los muertos o a los ancestros. Este modelo de terraza con hornacinas es un antecedente de la terraza con nichos ubicada en el frente occidental del Templo del Sol (Franco, 1996). En la parte baja también habían recintos y depósitos en uno de los cuales se encontró los restos disturbados de algún señor importante de la administración Inca

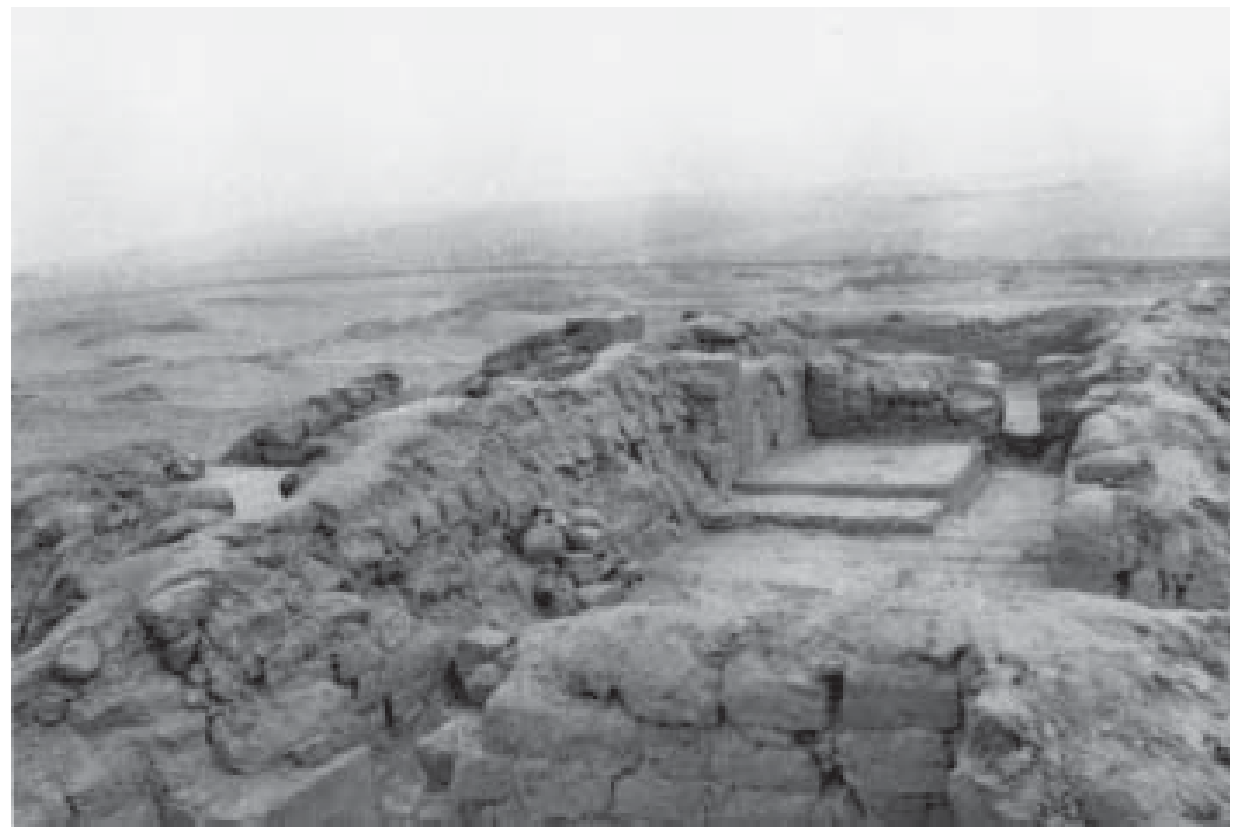

Fig. 23 - Recinto mayor con banqueta en el volumen piramidal . 


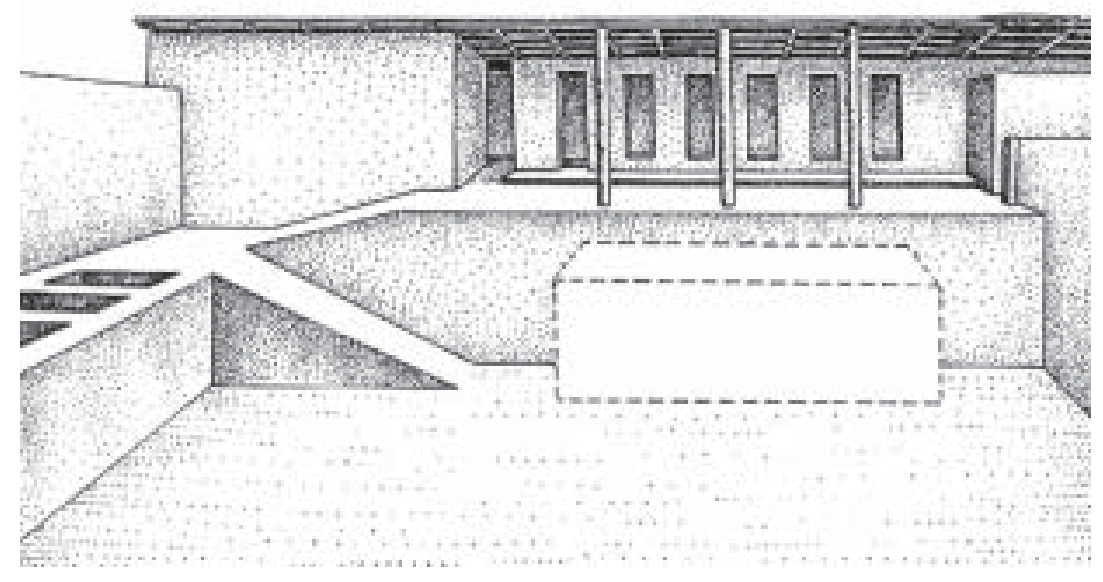

Fig. 24 - Reconstrucción hipotética del sector funerario (sector IX) de la Pirámide con Rampa $n^{0} 2$.

cuya tumba fue tal vez saqueada en la época de la extirpación de idolatrías (Franco, 1998: 20-21). En consecuencia podemos decir que a la muerte de algún señor importante, las exequias se realizaban en el patio principal que luego culminarían en el ambiente dedicado a los ancestros.

Hay otro sector hacia el oeste de la pirámide (sector VI) que presenta un conjunto de recintos que forman una " $U$ " orientada al Oeste, con un patio central con banquetas laterales. Tiene recintos con banquetas y depósitos pequeños que sirvieron para guardar las despensas. Además se ubicó un recinto especial caracterizado por la presencia de un altarcillo (Franco, 1998: 20) (Fig. 25). Las excavaciones en el recinto más grande de este sector revelaron que hubo un movimiento telúrico que derribó los muros sobre los utensilios de cerámica Inca (Fig. 26). Es posible que este sismo fue el que experimentaron los españoles un día antes de su arribo a Pachacamac.

El sector VI se vincula hacia el Este con un patio hundido (sector V), dentro del cual se concentró mucha basura como producto de un alto consumo de alimentos y desechos utilitarios que dejaron los ocupantes del sector VI en la época Inca. Por la calidad de los utensilios y la presencia de cerámica imperial, sospechamos que este sector estuvo ocupado por una familia o Panaca Real. Los ocupantes del sector VI tuvieron acceso a un sector ubicado en la parte baja del lado norte del volumen piramidal, donde se ubicaban ambientes especiales para el culto, los cuales se asocian a un depósito en forma de cruz.

Por toda la información que tenemos al presente podemos deducir que la Pirámide con Rampa $n^{\circ} 2$ es el modelo más completo de un edificio de este tipo en Pachacamac; siempre merece ser tomarda en cuenta para tener referencias con relación a su diseño, secuencia y función de sus espacios arquitectónicos. 


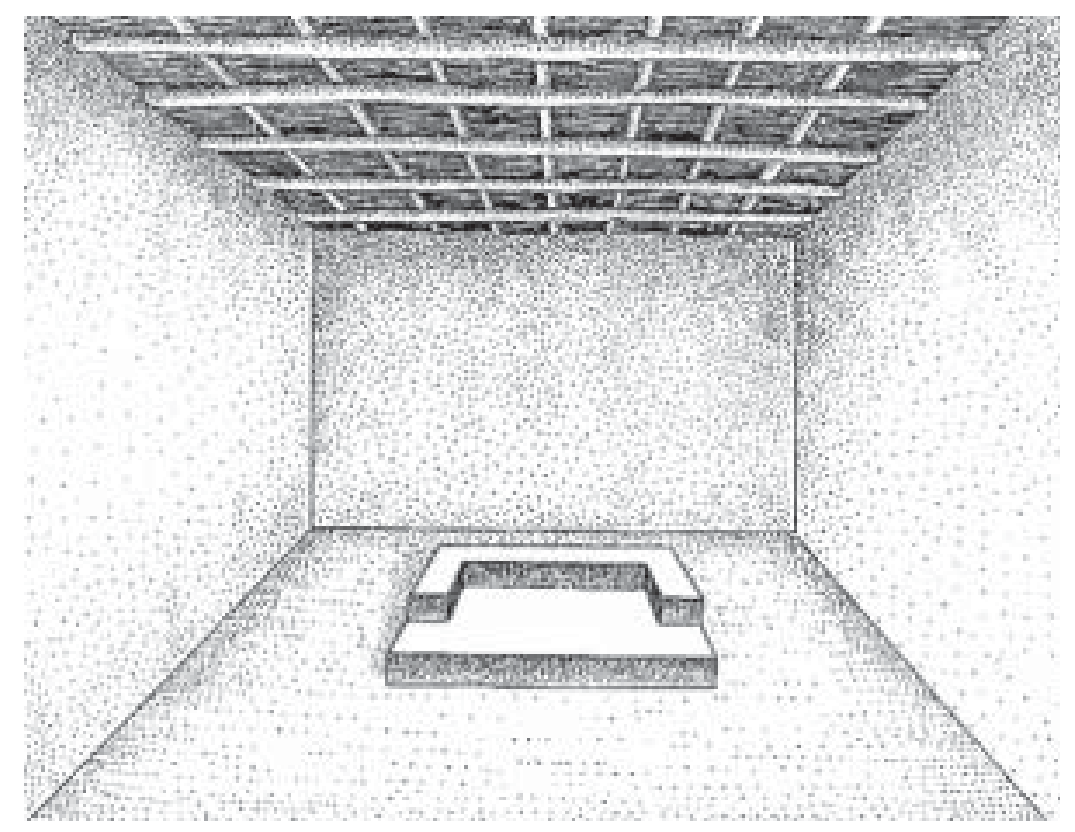

Fig. 25 - Reconstrucción hipotética de un altarcillo (sector VI) de la Pirámide con Rampa $\mathbf{n}^{\circ} 2$.

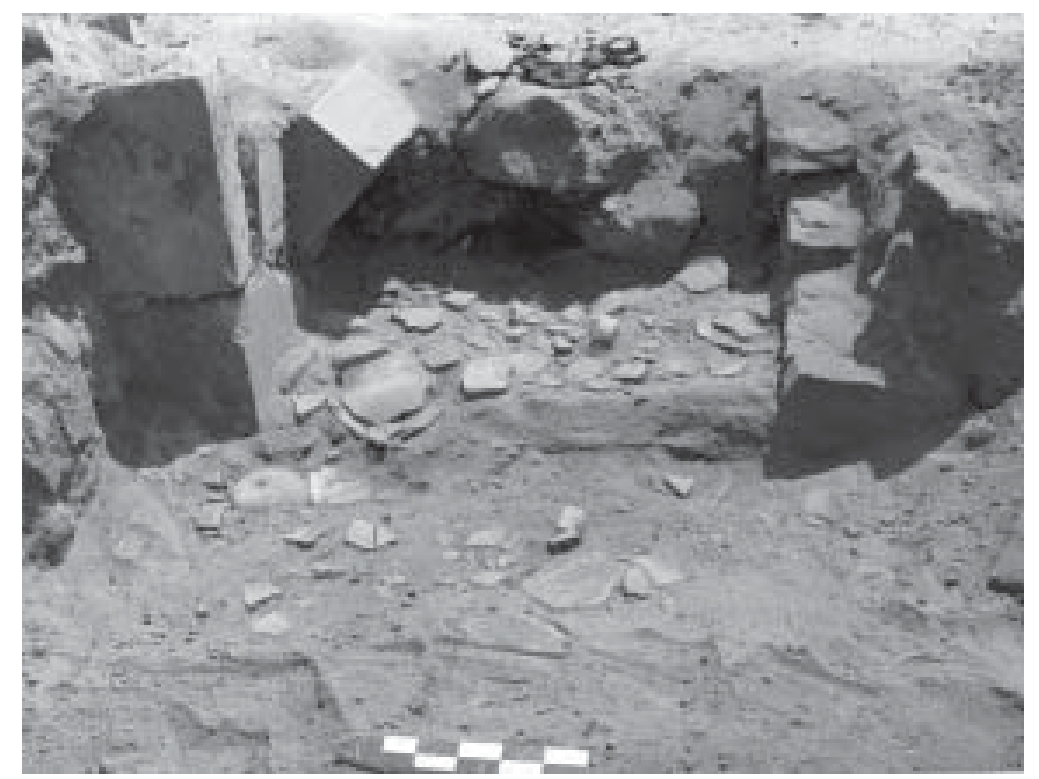

Fig. 26 - Vano de acceso de uno de los recintos del sector VI, donde se observan los restos de recipientes aplastados por los escombros como consecuencia de un sismo. 


\section{APRECIACIONES SOBRE LA SECUENCIA ALFARERA}

Por algunos resultados estratigráficos conocidos hasta el momento de excavaciones principalmente realizadas en el Templo Viejo y la Pirámide con Rampa n ${ }^{\circ}$ 2, se puede establecer una secuencia de grupos cerámicos y la introducción de nuevos estilos en el centro ceremonial.

Las excavaciones del Templo Viejo y algunas evidencias ofrecidas por Max Ühle (1903) nos permiten asumir que el estilo de cerámica tricolor de uso ceremonial ofrendada en el Templo Viejo (Cf. Franco \& Paredes, 2000: 620-628) (Figs. 27, 28 y 29), es más antiguo que el grupo de cerámica doméstica de cántaros llanos sin pintura o pintados de color amarillo pálido tenue (Fig. 30) y el grupo de cerámica incisopunzonado que fueron encontrados en distintos sectores de Pachacamac, principalmente en la Pirámide $n^{\circ} 2$. En este último edificio se encontraron sobre el nivel rocoso, recintos de adobe y piedra de uso doméstico (Figs. 31, 32 y 33), asociados a fragmentería de cerámica llana y a veces pintada con figuras reticulares o bandas de pintura amarillo pálido sobre el color natural de la cerámica (Franco, 1998: 44-47), que corresponden a la misma familia de los cántaros del Templo Viejo (Franco \& Paredes, 2000: 615-616). El otro grupo de cerámica con un estilo definido es el inciso-punzonado (Fig. 34) que aparece al sur del Templo Viejo y debajo del Templo del Sol. Algunas formas conocidas son de escudillas y cuellos convexos de cántaros decoradas con figuras geométricas.

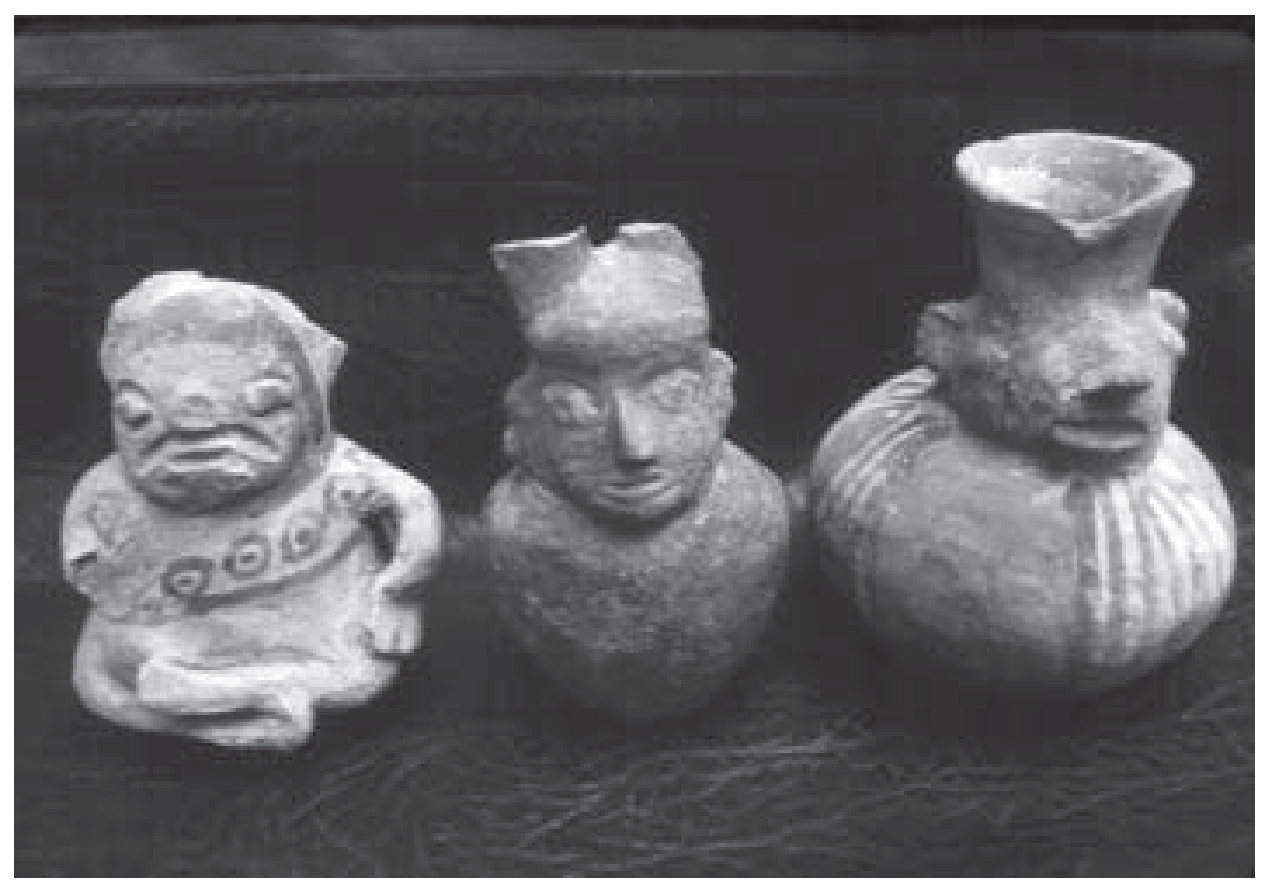

Fig. 27 - Botellas antropomorfas con representación de personajes de frente, asignadas a la Época 3 del Horizonte Medio. 


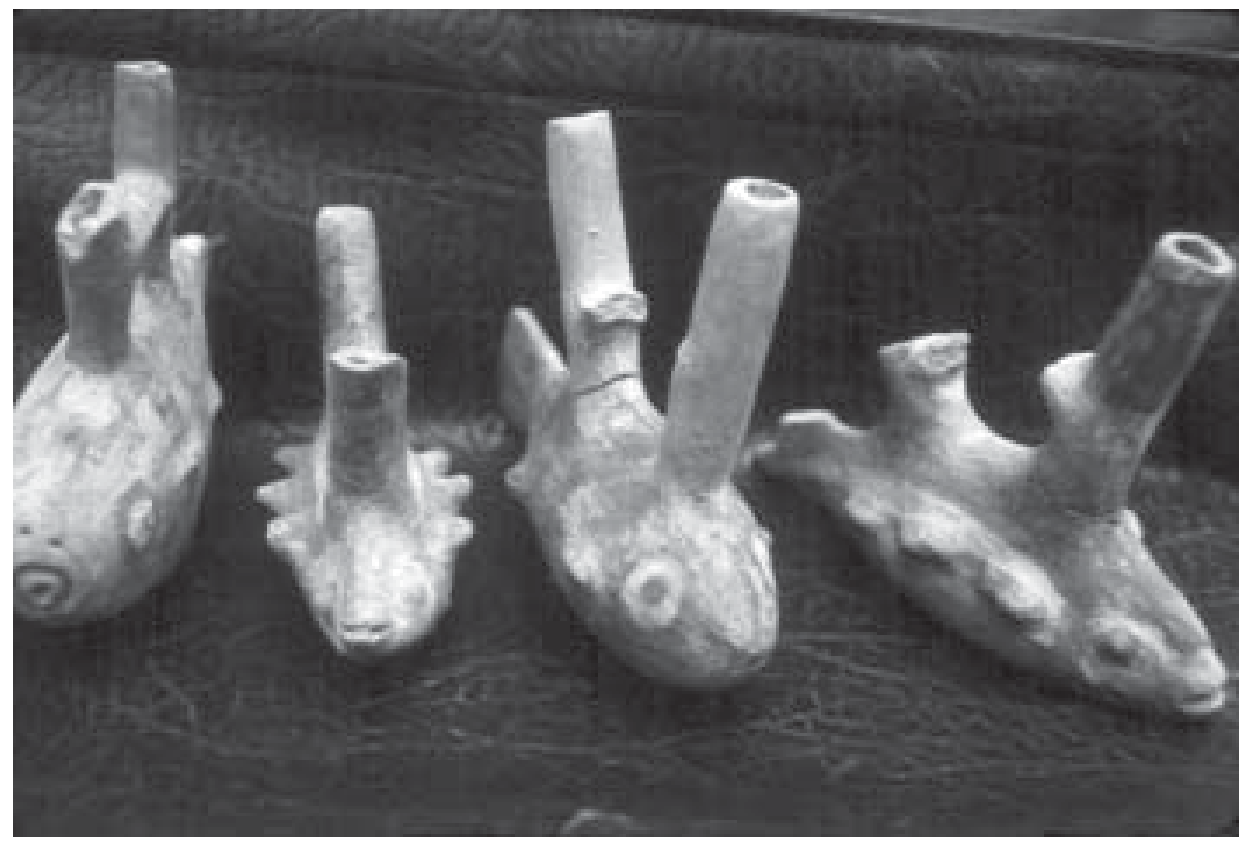

Fig. 28 - Botellas con representaciones de peces, asignadas a la Época 3 del Horizonte Medio.

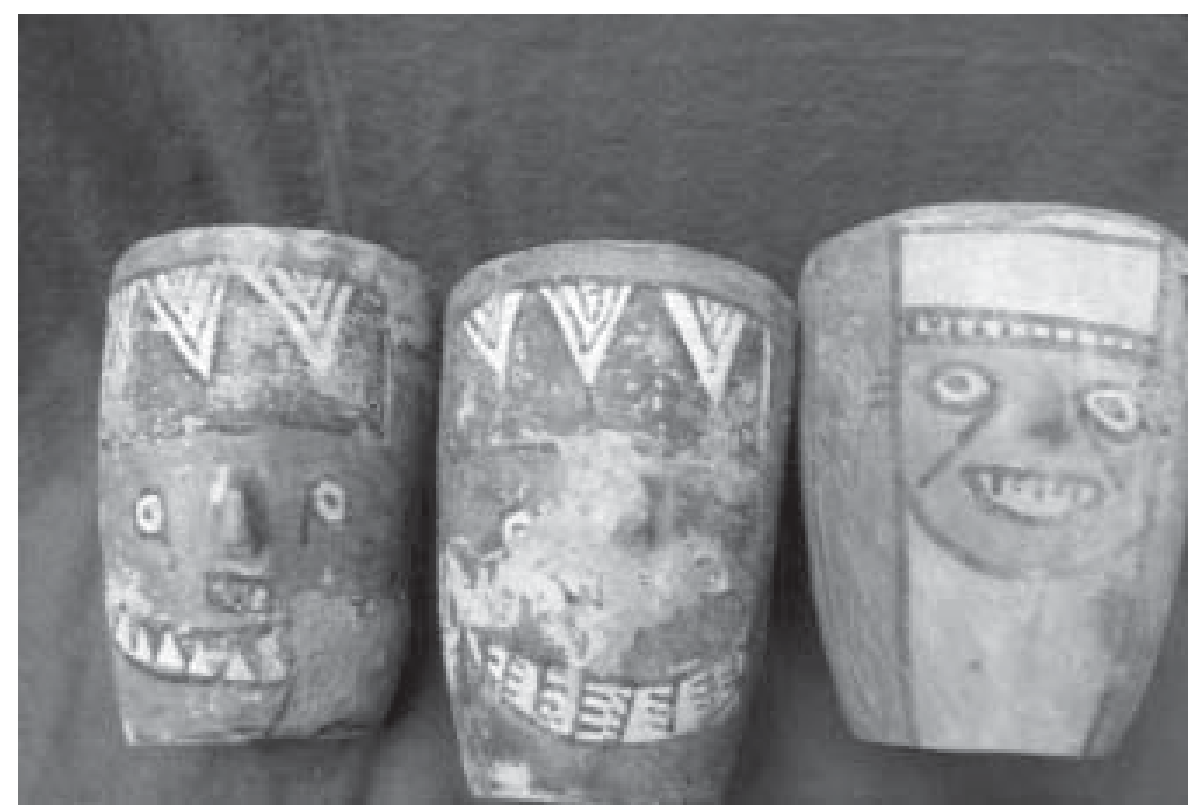

Fig. 29 - Vasos con rostros y motivos geométricos, asignadas a la Época 3 del Horizonte Medio. 


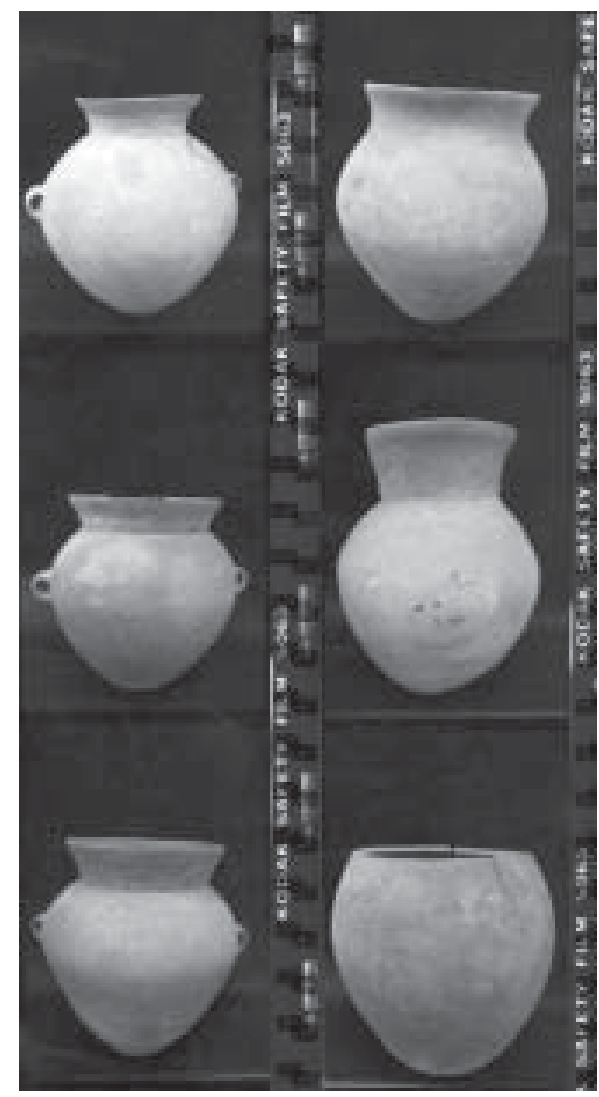

Fig. 30 - Cántaros recuperados en las excavaciones del Templo Viejo.

Tenemos el caso particular de una asa con la representación de un batracio escultórico incidido, que es un tema vinculado al culto al agua, que viene a ser un antecedente cercano de los batracios que se representaron en la alfarería del grupo marrón sobre crema del Intermedio Tardío. Otro fragmento con la misma técnica fue hallado en la Pirámide con Rampa ${ }^{\circ} 3$ (Cf. Eeckhout, 1995: 77-79), así como también en el sector de las Palmas (Paredes \& Ramos, 1994: 339-340). Uhle también encontró en una tumba al pie del Templo de Pachacamac (Cf. Shimada, 1991: Lámina 8 - fig. 9), una botella de influencia Lambayeque con diseños incisos en el cuerpo de la vasija. Uno de los problemas que todavía afrontamos, debido a que no contamos con una muestra significativa de este grupo cerámico, es la relación de este alfar con el estilo "Teatino" inciso-punzonado del área Chancay-Chillón, a juzgar por la técnica decorativa y las representaciones (Franco, 1998: 60-61). En términos de cronología relativa, este grupo cerámico aparece en Pachacamac probablemente hacia fines de la Época 3. Todavía no hay datos suficientes para discutir la comparación del inciso-punzonado de Pachacamac con el inciso punzonado del área nor-central costeño, aunque por lo pronto encontramos algunas variaciones morfológicas y cronológicas, porque el estilo Teatino ha sido 


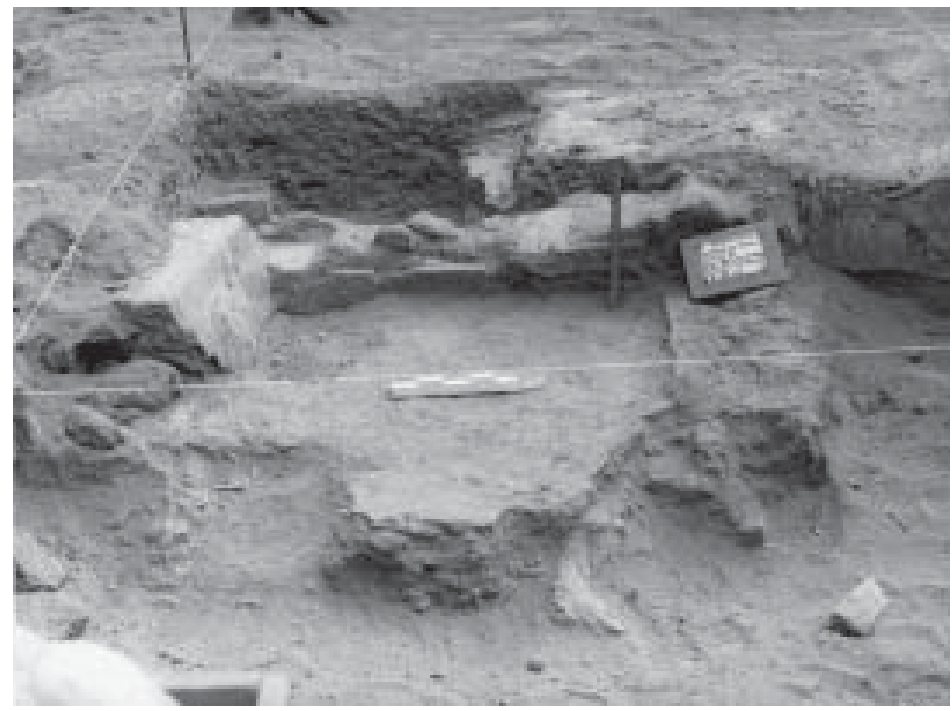

Fig. 31 - Pequeño recinto de piedra y adobe de uso doméstico, asociado a niveles tempranos antes de la construcción de la Pirámide con Rampa n 2.

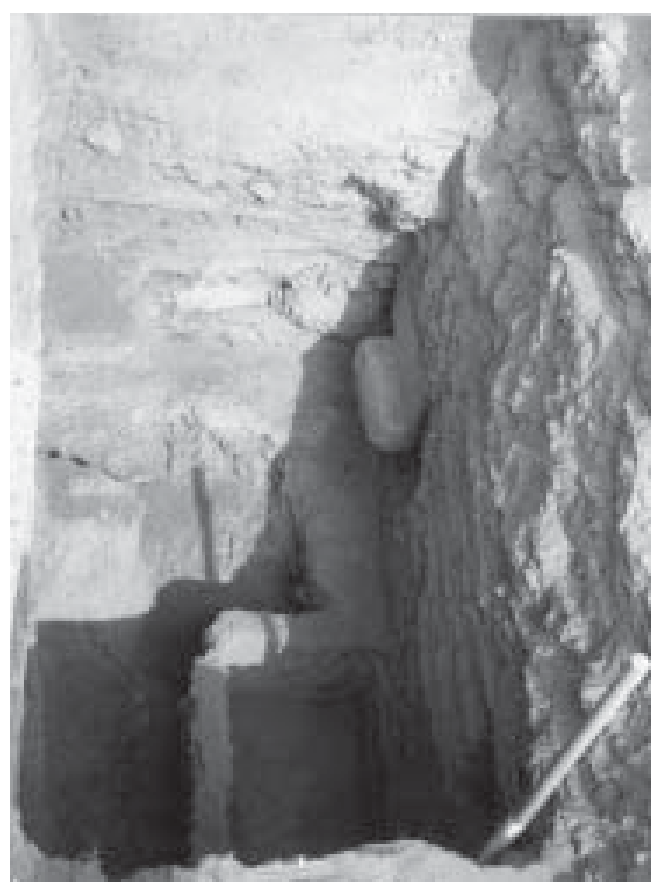

Fig. 32 - Vista parcial de recintos de adobe de uso doméstico, asociado a niveles tempranos antes de la construcción de la Pirámide con Rampa no 2. 

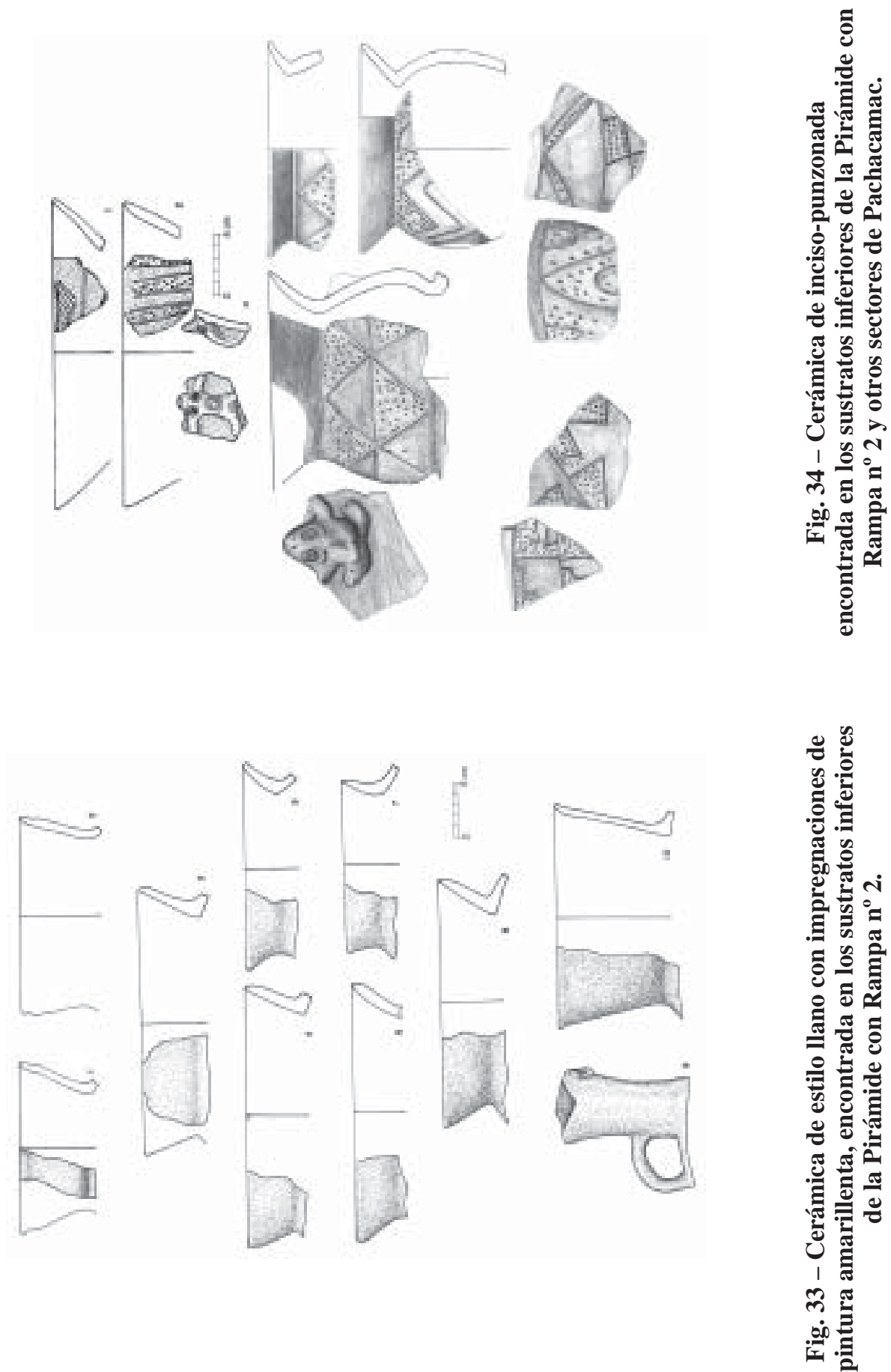
ubicado dentro del Horizonte Medio 2 y 3 (Bonavia, 1959; Kaulicke, 1997; Villacorta $\&$ Tosso, 2000). Por lo pronto podríamos sugerir que este estilo inciso-punzonado es un derivado del grupo Teatino, aun cuando no hay datos confiables sobre la presencia de este tipo de alfar en el valle del Rímac por ser un área intermedia; esto se debe quizás al poco interés por investigarla. Solo tenemos algunas muestras de cerámica con algunas variantes morfológicas encontradas en los sitios de Santa Catalina y Conde de la Torre, que hace muchos años fue considerada como"“Ichimay inicial" (Bazán, 1992a: 20-28, 31).

A partir de la desaparición de los grupos anteriormente esbozados, se introducen en Pachacamac una variedad de vasijas de diferentes formas que han sido encontradas en los sustratos inferiores de la Pirámide con Rampan ${ }^{\circ} 2$ (Franco, 1998: 45-50). El grupo de alfares registrados en capas subyacentes al primer piso del patio, fue también utilizado por los constructores de la pirámide. Existe una variedad de tipos, en su mayor parte cerámica doméstica (Figs. 35 y 36). Tenemos el caso de un cuello aquillado de un cántaro cuya forma comparamos con una vasija completa encontrada en el valle del Rímac y que ha sido considerado como "botella Ichma-fitomorfo" ubicada dentro de la

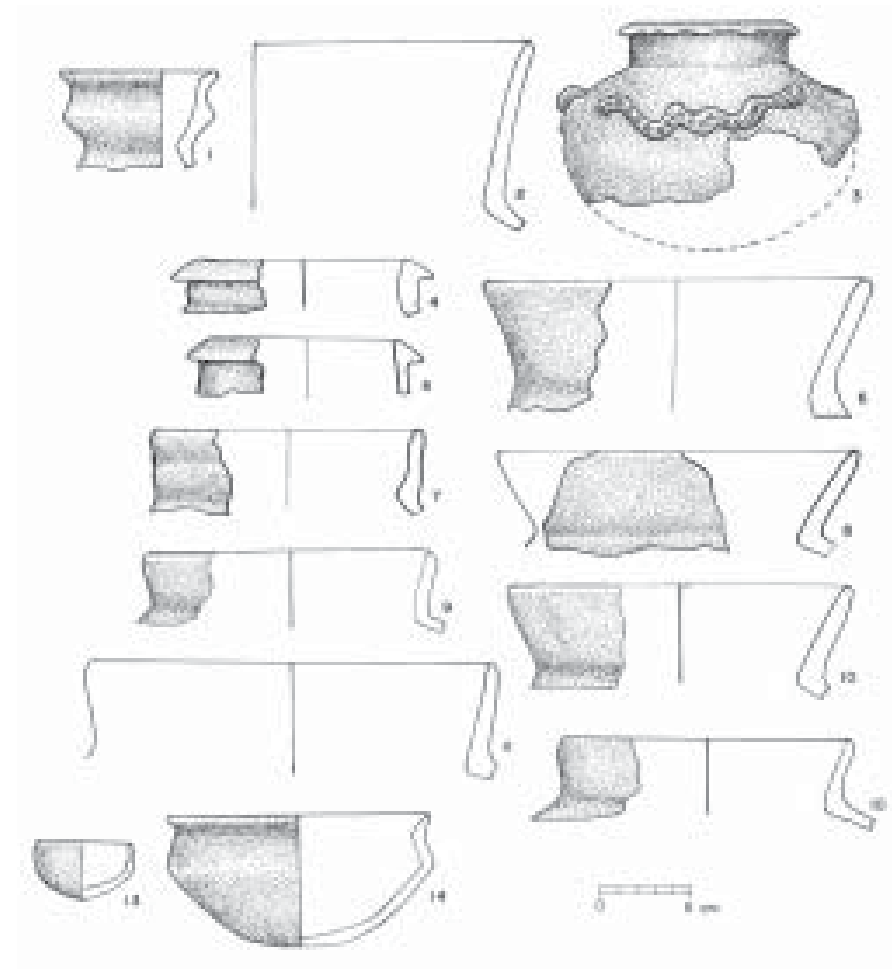

Fig. 35 - Cerámica doméstica del patio principal, asociada a la ocupación temprana de la Pirámide con Rampa no 2. 


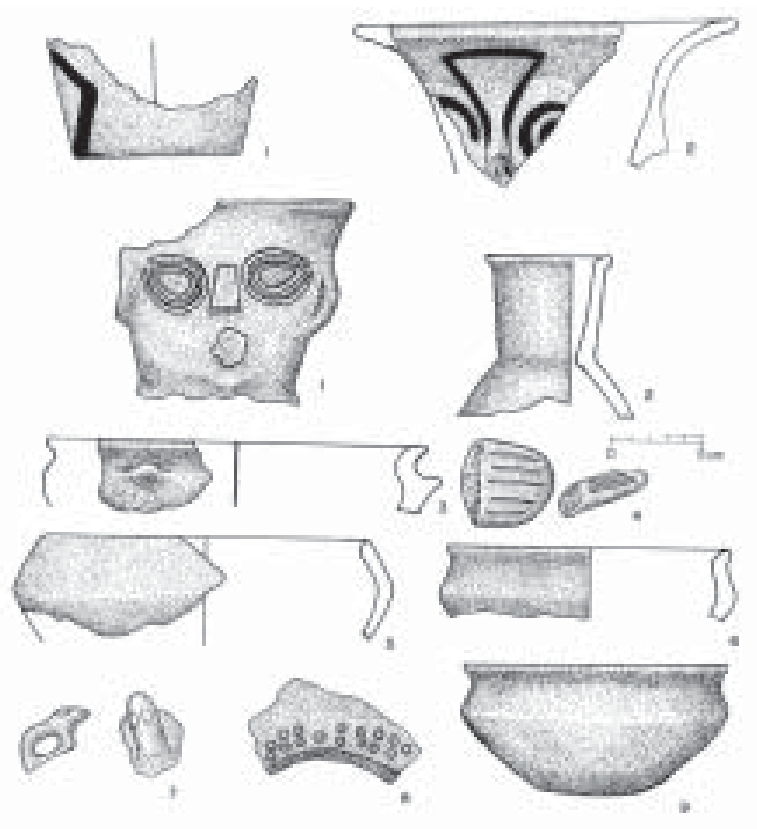

Fig. 36 - Cerámica doméstica del patio principal asociada a la ocupación temprana de la Pirámide con Rampa no 2.

época Ichma Medio (Bazán, 1991). Hay cántaros cara-gollete con pintura marrón oscuro sobre amarillo pálido que en otros casos es considerada como marrón sobre crema (Bazán, 1992a: 20). Hay también vasijas abiertas y escudillas de paredes rojizas, vasijas cerradas carenadas pintadas de color amarillo pálido o blanco en el tercio superior y rojo oscuro o color concho vino en el cuerpo inferior que sigue la tradición de la pintura de las vasijas del Horizonte Medio. Se suman algunos fragmentos de ollas de uso doméstico trabajadas en cerámica oxidada con elementos decorativos en relieve de serpientes con diseños incisos o impresos y un cara-gollete en color negro de lados divergentes con tratamiento inciso y ojos alados de profunda influencia Lambayecana. También se recuperaron fragmentos con pintura tricolor (rojo, negro, blanco), donde el color negro y blanco aparecen siempre unidos en líneas delgadas sobre un fondo rojo oscuro, representando esta colección como una de las de mayor valor tecnológico. Desafortunadamente no hemos recuperado vasijas enteras de este tipo para su mejor estudio, pero más bien, se observó algunas piezas de este estilo en el museo de sitio, tratándose de cántaros con motivos figurativos delineados de negro y pintados de color amarillo pálido o blanco sobre un engobe rojizo, lo que se definiría como vasijas tricolor con motivos figurativos y de personajes de frente con cara-gollete y cuerpo pintado que han sido caracterizadas como uno de los estilos clásicos Ichimay. En otros casos son cántaros simples engobados de rojo y pulidos.

Tenemos otro grupo de cerámica del tipo marrón oscuro sobre amarillo pálido (Figs. 37 y 38). Las vasijas más representativas son ollas de cuerpo aquillado, base convexa 

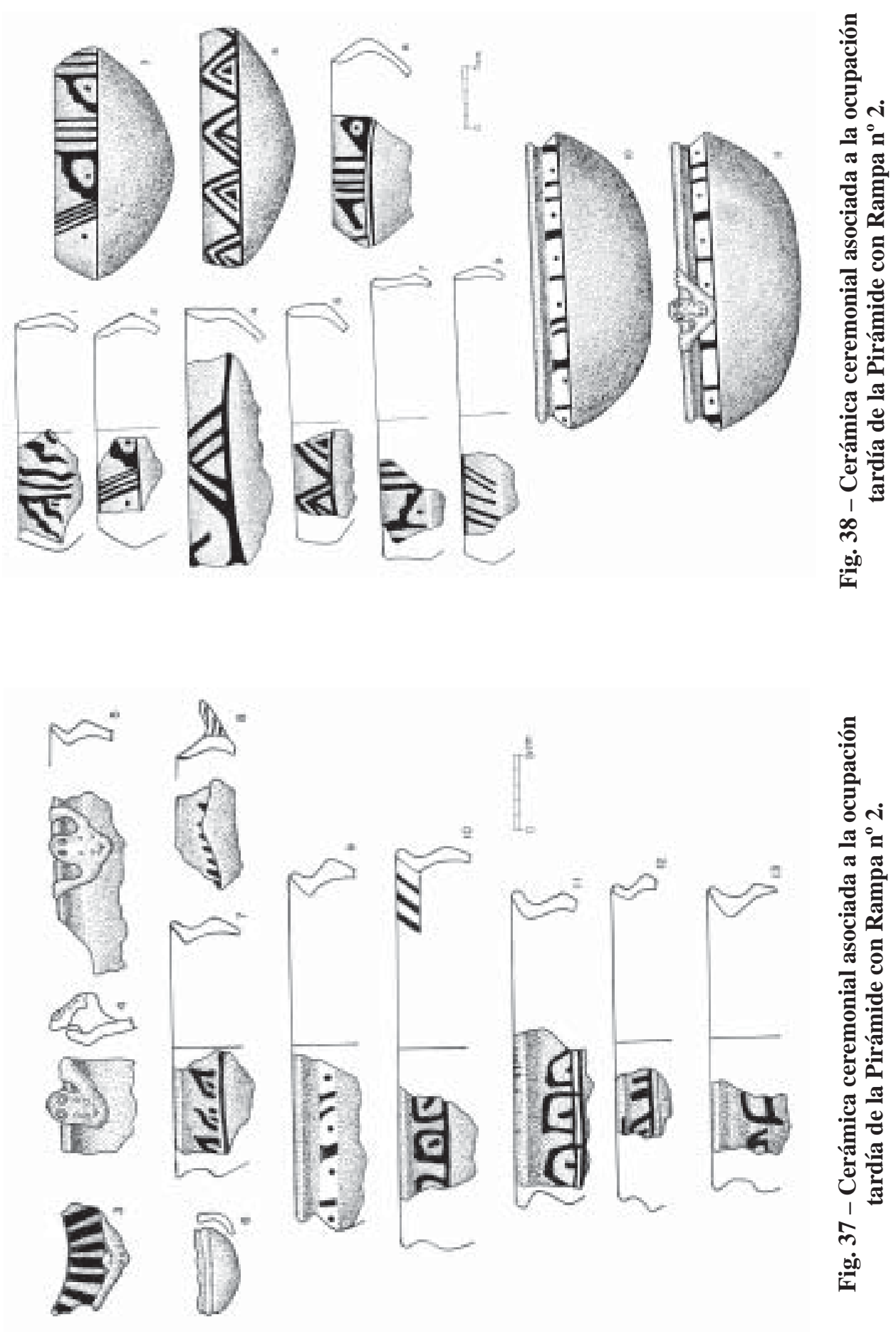
o redondeada, con batracios escultóricos (Buffo spinolosus) adheridos al borde. Hay otros recipientes con carena en el tercio superior del cuerpo, donde aparecen cabezas de aves marinas de pico largo u otras veces son agarraderas compactas. Hay que advertir que este grupo de cerámica siguió produciéndose hasta la época Inca, lo que sugiere que los incas aprueban y mantienen la producción de este estilo cerámico para los ritos propiciatorios del agua. Hace muchos años, observé en una exposición de la Casona de San Marcos una colección de cerámica de este estilo proveniente de Armatambo, al parecer encontrado asociado a una ocupación Inca. La diferencia con los de Pachacamac radica en que los fragmentos de Armatambo tenían una tonalidad más verdosa o clara. Llama mucho la atención que este grupo de cerámica aparece — hasta donde sabemos — en las partes bajas de los valles de Lurín y Rímac. Sería interesante que en el futuro se investigue este tipo de cerámica para establecer su origen y distribución.

Asimismo son reconocibles algunos fragmentos de piezas de estilos locales con influencias de estilos foráneos. Por ejemplo se encontró un par de piezas gemelas fitomorfas en color negro que parecen, junto con otras, tener influencia Chimú. De otro lado, se destaca la abundancia de fragmentería de estilo Inca policromo en todas sus formas, que ha sido primero bautizado por Uhle (1903) como "estilo Cuzco" y denominado por Strong \& Corbett (1943) como estilo "Inca Policromo" o "IncaPachacamac" (Lavallée, 1969: 241). Este grupo de cerámica Inca, si bien es cierto que estilísticamente es inconfundible, algunas veces la pasta y los colores empleados hacen pensar en la utilización de materiales locales. De ahí puede desprenderse que muchos alfareros están produciendo cerámica Inca imperial en la costa.

El análisis de temperantes del grupo de cerámica del Intermedio Tardío, realizado en el departamento de Geología de la Universidad Nacional Mayor de San Marcos, dio como resultado la utilización de cuarzo hialino, partículas líticas angulosas, yeso, feldespato blanco con impregnaciones de óxido, feldespato blanco cremoso, feldespatos blancos oscuros y arcilla cocida molida. No necesariamente todos los temperantes están juntos, más bien se encuentran alternados.

\section{CONCLUSIONES Y COMENTARIOS}

Después del colapso de la cultura Regional Lima, el centro religioso de Pachacamac desempeñó una función ideológica predominante de carácter interregional, cuyo culto a la deidad Pachacamac se centralizó en el Templo Viejo. Las evidencias indican que hubo muchos cambios en la arquitectura, debido principalmente a la presencia de un meganiño que determinó la modificación del edificio y la introducción de una nueva ideología que cumplió el rol de mediador entre las regiones del norte y del sur.

Un segundo meganiño averió la arquitectura del Templo Viejo, lo que precipitó la culminación de una nueva sede para el culto a Pachacamac, cuyo auge se desarrolló durante la Época 3 del Horizonte Medio. Los diferentes programas decorativos en el nuevo edificio estuvieron relacionados con la propiciación del mundo doméstico, carácter ideológico que se impuso a raíz del desorden climático.

La aparición de arquitectura de tipo doméstico que se encuentra en las bases de las PCR, reflejan una ocupación de ciertos grupos de migrantes altoandinos que, 
sacudidos por una sequía ocurrida hacia los primeros siglos de la segunda parte del milenio anterior, arribaron a Pachacamac. Estos grupos humanos usaron cántaros y vajillas de cerámica llana y otras decoradas con la técnica del inciso-punzonado.

Después de la crisis, hay una reestructuración del centro ceremonial con la aparición de las PCR en Pachacamac. Este modelo de restructuración se repitió en otros centros religiosos importantes como por ejemplo, Cajamarquilla en el Rímac, Pisquillo Chico en Chancay, Pacatnamú en Pacasmayo, Túcume y Batán Grande en Lambayeque, entre otros.

El modelo de PCR se difundió en menor tamaño hacia el interior del valle de Lurín, en los sitios de Pampa de las Flores, Panquilma y Tijerales, y en otros sitios menos importantes asociados a asentamientos rurales. Así también, el modelo se difundió hacia el norte, en el valle del Rímac, en los sitios de Armatambo y Huaquerones, extendiéndose quizás hasta Chancay. Pacatnamú sería el modelo más lejano de las PCR, con ciertas variaciones, pero con la misma función. Todo esto indica que el centro ceremonial se convirtió en una especie de confederación religiosa con la representatividad de los señoríos más prestigiosos de los valles costeños. Los que se establecieron eran las representaciones o embajadas que tenían cierto prestigio con el poder religioso central y los que a la vez tenían poder económico para tributar a la deidad principal y a los sacerdotes que lo representaban.

Se ha tomado como referencia la Pirámide con Rampa n ${ }^{\circ}$ 2, como un modelo de la manera de funcionar de una unidad piramidal completa. A partir de los rasgos arquitectónicos, se definió la función de los distintos espacios ceremoniales, demostrándose que el centro de las actividades ceremoniales fue el volumen piramidal que funcionó como un anfiteatro, con directa interrelación con el patio principal delantero donde se realizaban las distintas celebraciones religiosas, especialmente vinculadas con ritos propiciatorios del agua. Asimismo se ha establecido un sector con viviendas (sector VI) para la instalación de un pequeño grupo humano relacionado con la élite. Cada sector como el del culto a los ancestros estaba dotado de depósitos o almacenes que servían para acumular los distintos productos y bienes que estaba relacionado con la tributación que ofrecía cada representación.

La alfarería del Intermedio Tardío ha sido recuperada de las excavaciones de la Pirámide con Rampa $n^{\circ} 2$, que representa una muestra no tan significativa como hubieramos querido, pero que por lo menos establece algunos estilos y formas conocidas dentro de la costa central. Uno de los grupos de cerámica que ha llamado nuestra atención son las vasijas de cuerpo carenado con pintura marrón sobre crema y con la representación de sapos escultóricos o aves marinas, cuya función estaba destinada para los ritos de libación asociados a la fertilidad, que se realizaban en el patio principal de la pirámide. Otros grupos son los clásicos cara-gollete pintados en rojo, crema o blanco y negro, cuya presencia se rastrea hasta la época Inca. Como hemos podido notar, algunas vasijas de cerámica Ychsma se seguían produciendo en la época Inca, y lo que significa que la producción de la cerámica Ychsma Intermedio Tardío no fue eliminada por la élite Inca. 
Por último, debo indicar que Pachacamac tiene que ser visto como un gran centro ceremonial de mucho prestigio y poder religioso en el antiguo Perú, que ha merecido muchas narraciones, comentarios y publicaciones desde la época de la conquista.

\section{Referencias citadas}

BAZÁN DEL CAMPO, F., 1991 - La Cultura Ichma. Revista de diario El Peruano, miércoles 18 de setiembre; Lima.

BAZÁN DEL CAMPO, F., 1992a-Arqueología de Lima. Evaluación del término Huancho. Los estilos de cerámica de Lima a fines del Horizonte Medio; Lima: De Crearte.

BAZÁN DEL CAMPO, F., 1992b - La urbe de Armatambo. Revista del diario El Peruano, viernes 17 de enero; Lima.

BONAVIA, D., 1959 - Sobre el estilo Teatino. Revista del Museo Nacional, 31: 43-93; Lima.

BONAVIA, D., 1985 - Mural Painting in Ancient Peru, 224p.; Bloomington: Indiana University Press. Traducción de P.J. Lyon.

BONAVIA, D., 1991 - Perú Hombre e Historia I. De los Orígenes al siglo XV, 586p.; Lima: Edubanco.

BUENO, A., 1974-1975 - Cajamarquilla y Pachacamac. Dos ciudades de la Costa Central del Perú. In: XXXIX Congreso Internacional de Americanistas 1970. Boletín Bibliográfico de Antropología Americana; México.

BUENO, A., 1982 - El antiguo valle de Pachacamac: Espacio, Tiempo y Cultura, segunda parte. Boletín de Lima, n 24: 10-29; Lima: Editorial Los Pinos.

CALANCHA, A. de la., 1976[1638] - Crónica Moralizadora del Orden de San Agustín en el Perú. In: Crónicas del Perú. Tomo III, Lima: Edición de Ignacio Prado Pastor.

CIEZA DE LEÓN, P., 1986[1550] - La Crónica del Perú; Lima: Ediciones Peisa. Biblioteca Peruana.

COBO, Fray B., 1956[1653] - Historia del Nuevo Mundo; Madrid: Ediciones Atlas. Biblioteca de Autores Españoles.

COOK, A., 1994 - Wari y Tiwanaku: entre el estilo y la imagen; Lima: Fondo Editorial de la Pontifica Universidad Católica del Perú.

DONNAN, C. \& COOK, G., 1986-The Pacatnamú Papers. Vol 1, 188p.; Los Angeles: Museum of Cultural History, University of California.

DULANTO, J., 2000 - Dioses de Pachacamac: El ídolo y el Templo, Lima: Banco de Crédito del Perú.

EECKHOUT, P., 1995 - Pirámide con Rampa nº 3 de Pachacamac, Costa Central del Perú. Resultados preliminares de la primera temporada de excavaciones (zona 1 y 2). Bulletin de l'Institut Français d'Études Andines, 24 (1): 65-106.

EECKHOUT, P., 1999-Pachacamac durant l'Intermédiaire récent. Étude d'un site monumental préhispanique de la Côte centrale du Pérou, 504p.; Oxford: BAR International Series 747.

EECKHOUT, P., 2000 - The Palaces of the Lords of Ichsma. An Archaeological Reappraisal of the Function of Pyramids with Ramps at Pachacamac, Central Coast of Peru. Journal of American Archaeology, $\mathbf{n}^{\circ}$ 17, 18 y 19: 217-254.

EECKHOUT, P., 2003a - Ancient Monuments and Patterns of Power at Pachacamac, Central Coast of Peru. Beiträge zur Allgemeine und Vergleichenden Archäologie, 23: 139-182. 
EECKHOUT, P., 2003b - Diseño arquitectónico, patrones de ocupación y formas de poder en Pachacamac, Costa central del Perú. Revista Española de Antropología Americana, 33: 17-37.

FRANCO JORDÁN, R., 1996 - El Templo del Sol de Pachacamac, Esplendor y Poder; Trujillo: Editorial DPI.

FRANCO JORDÁN, R.,1998 - La Pirámide con Rampa nº 2 de Pachacamac. Excavaciones y Nuevas Interpretaciones; Trujillo.

FRANCO, R. \& PAREDES, P., 2000 - El Templo Viejo de Pachacamac: Nuevos Aportes al Estudio del Horizonte Medio. Huari y Tiwanaku: Modelos vs. Evidencias. Boletín de Arqueología PUCP, $\mathbf{n}^{\circ}$ 4: 607-630; Lima.

HECKER, G. \& HECKER, W., 1985 - Pacatnamú y sus Construcciones: Centro Religioso en la Costa Norte Peruana, 244p.; Frankfurt: Verlag Klaus Dieter Vervuert.

HEYERDAHL, T., SANDWEISS, D., NARVAEZ, A. \& MILLONES L. (eds.), 1996 - Túcume, 353p.; Lima: Banco de Cédito del Perú, Colección Artes y Tesoros del Perú.

HORKHEIMER, H., 1970 - Chancay Prehispánico: Diversidad y Belleza. In: 100 Años de Arqueología en el Perú: 363-391; Lima: Ediciones de Petróleos del Perú. Introducción, Selección Comentarios y notas por Rogger Ravines.

JIMENEZ BORJA, A., 1985 - Pachacamac. Boletín de Lima, no 35: 40-54; Lima.

KAULICKE, P., 1997-Contextos Funerarios de Ancón. Esbozo de una Síntesis Analítica, 123p.; Lima: Fondo Editorial de la Pontificia Universidad Católica del Perú.

LAVAllÉE, D., 1969 - Una Colección de Cerámica de Pachacamac. Revista del Museo Nacional, 34: 220-246; Lima.

MENZEL, D., 1964 - Style and Time in The Meddle Horizont. Nawpa Pacha, 2: 1-105.

MENZEL, D., 1968 - La Cultura Huarí, 233p.; Lima: Peruano-Suiza. Colección Las grandes civilizaciones del Antiguo Perú.

MICHCZYNSKI, A., EECKHOUT, P. \& PAZDUR, A., $2003-{ }^{14}$ C Absolute Chronology of Pyramid III and the Dynastic Model at Pachacamac, Perú. Radiocarbon, 45(1): $59-73$.

MOGROVEJO, J. D. \& SEGURA, R., 2000 - El Horizonte Medio en el conjunto arquitectónico Julio C. Tello de Cajamarquilla. Boletín de Arqueología, 4: 565-582; Lima: PUCP.

MOSELEY, M. E. \& FELDMAN, R., 1982 - Vivir con crisis: percepción humana de proceso y tiempo. Revista del Museo Nacional, 46: 267-287; Lima.

MUELLE, J. C. \& WELLS, R., 1939 - Las Pinturas del Templo de Pachacamac. Revista del Museo Nacional, VIII, 2: 275-282; Lima.

NIALS, F., DEES, E., MOSELEY, M., POZORSKI, S., POZORSKI, T. \& FELDMAN, R., 1979 - El Niño: The catastrophic flooding of coastal Peru. Field Museum of Natural History Bulletin, 50 (7) y (8): 4-14 y 4-10; Chicago.

PAREDES, P., 1985 - La Huaca Pintada o el Templo de Pachacamac. Boletín de Lima, 41: 7077; Lima.

PAREDES, P., 1988 - Pachacamac, Pirámide con Rampa nº 2. Boletín de Lima, 55: 41-58.

PAREDES, P., 1991 - Pachacamac. In: Los Incas y el Antiguo Perú, 3000 Años de Historia. Tomo I: 364-383; Barcelona: Sociedad estatal Quinto Centenario.

PAREDES, P. \& FRANCO, R., 1985 - Excavaciones en la Huaca Pintada o el Templo de Pachacamac. Boletín de Lima, 7 (41): 78-84; Lima.

PAREDES, P. \& FRANCO, R., 1987 - Pachacamac: Las Pirámides con Rampa, cronología y función. Gaceta Arqueológica Andina, 13: 5-7; Lima.

PAREDES, P. \& RAMOS, J., 1994 - Excavaciones Arqueológicas en el Sector las Palmas, Pachacamac Boletín de Lima, Vol. XVI, no 91-96: 313-349; Lima.

ROSTWOROWSKI, M., 1977 - Etnia y Sociedad. Costa Peruana Prehispánica, 293p.; Lima: IEP.

ROSTWOROWSKI, M., 1986 - Estructuras Andinas de Poder, 202p.; Lima: IEP. 
ROSTWOROWSKI, M., 1992 - Pachacamac y el señor de los milagros: una trayectoria milenaria, 214p.; Lima: IEP.

SHADY, R., 1982 - La cultura Nievería y la Interacción Social en el Mundo Andino en la Época Huari. Arqueológicas, 19: 7-108; Lima.

SHIMADA, I., 1991 - Pachacamac Archaeology: Retrospect and Prospect. In: Pachacamac. A reprint of The 1903 edition by Max Uhle, 103 p.; Philadelfia: University of Pensilvania. The University Museum of Archaeology and Anthropology.

SHIMADA, I., SCHAAF, C., THOMPSON, L. \& MOSLEY-THOMPSON, E., 1991 Implicaciones culturales de una gran sequía del siglo VI d. C. en los Andes peruanos. Boletín de Lima, 13 (77): 33-56; Lima.

STRONG, W. \& CORBETT, J., 1943 - A Ceramic sequence at Pachacamac Arqueological studies in Perú, 1941-1942. Columbia Studies in Arqueology and Etnology, Vol. I, nº 2: 27-121; New York: Columbia University Press.

THOMPSON, L., MOSELEY-THOMPSON, E. \& MORALES, B., 1985-A 1500 - Year Record of Tropical Precipitation in Ice Cores from the Quelccaya Ice Cap, Peru. Science, 229: 971-973.

UHLE, M., 1903 - Pachacamac. Report of the William Pepper, M.D.LL.D. Peruvian Expedition of 1896. The Departament of the University of Pennsylvania.

VILLACORTA, L.F.\& TOSSO, W., 2000-El estilo Teatino: nuevas evidencias. Arqueológicas, 24: 79-124; Lima: Museo Nacional de Arqueología, Antropología e Historia del Perú. 